\title{
The Mathematics-Oriented Epistemological Belief Scale (MOEBS): Validity and Reliability Study
}

\author{
Mustafa ILHAN*
}

\author{
Bayram ÇETIN ${ }^{* *}$
}

Received: 30 November 2012

Accepted: 09 May 2013

\begin{abstract}
The present study aims to develop a valid and reliable instrument to measure high school students' mathematics-oriented epistemological beliefs. The participants were 406 high school students studying in Batman and Diyarbakır infall of 2012 who were considered under two separate study groups. Expert review was done to check content and face validity. The exploratory factor analysis (EFA) and confirmatory factor analysis (CFA) were performed in order to check construct validity. As a result of the EFA, a 27-itemthree-factor structure emerged, explaining $40.57 \%$ of variance. The emerging factors were called as a belief of that learning depends on effort (BLDE), a belief of that learning depends on talent (BLDT), and a belief of that there is only one truth (BTOOT). The findings indicated all 27 items and a three-factor structure related to the MOEBS have satisfactory indices of goodness of fit.As a result of reliability analysis, it was determined that internal consistency and test-retest coefficients were acceptable.The findings of the item analyses showed that all of the items were discriminatory. In light of these findings, it can be argued that the scale is reliable and valid and can be used to measure high school students' mathematics-oriented epistemological beliefs.
\end{abstract}

Keywords: mathematics-oriented epistemological belief, the mathematics-oriented epistemological belief scale, reliability, validity.

\section{Extended Abstract}

Purpose and Significance:A review of theliterature revealed that an instrument to measure mathematics-oriented epistemological beliefs has been lacking inTurkish culture.Mathematics-oriented epistemological beliefs are significant in mathematics education since determining mathematics-oriented epistemological beliefs may guide decisions on how to support students, how to organize learning environments, and how to develop mathematics curricula.Therefore, it is of great significance to developa Turkish instrument to determine students' epistemological beliefsregarding mathematics.In this respect, the present study aims to develop a valid and reliable instrument to measure mathematics-oriented epistemological beliefs.

Method:The participants were 406 high school students studying in Batman and Diyarbakır in fall of 2012 who were considered under two separate study groups.The first group comprised 315 students, 182 of whom were female (57.80\%) and 133 were male $(42.20 \%)$, who were studying in five different high schools in Batman, Turkey. Data obtained from this group of students were analyzed to check construct validity, concurrent validity,calculate internal consistency coefficients and to do item analysis. The second group comprised 91 students, 39 of whom were female (38.46\%) and 52 of

*Res. Assist., Dicle University, Diyarbakir, Turkey, mustafailhan21@gmail.com

*Assoc.Prof. Dr., Gaziantep University, Gaziantep, Turkey, bcetin27@gmail.com 
whom were male (57.14\%), who were studying in Silvan Anatolian Teacher High School, Diyarbakır, Turkey. Data obtained from this group were analyzed to check testretest reliability. The MOEBS was developed upon the BLDE, BLDT and BTOOT subscales developed by Schommer (1990) and adapted into Turkish by Deryakulu and Büyüköztürk (2002, 2005).11 items under the BLDE, 10 items under the BLDT, and 14 items under the BTOOTformed an item pool of 35 items. Expert review was done to check content and face validity. The exploratory factor analysis (EFA) and confirmatory factor analysis (CFA) were performed in order to check construct validity. In terms of concurrent validity, the correlation between students' scores obtained from the MOEBSand mathematics achievement scores was calculated.Students' previous year' GPA scores of mathematics were considered as mathematics achievement scores. Considering the fact that the BLDEscores indicate well-developed epistemological beliefsand high scores from the BLDT and the BTOOT indicate underdeveloped epistemological beliefs, it was hypothesized that a positive relationship will be between the BLDE and mathematics achievement, and a negative relationship will bebetween the BLDT and the BTOOTand mathematics achievement. Thereliability coefficients were calculated by means of internal consistency and test-retest method.In order to determineitems' discriminatory and predictive power, scores of both top and bottom $27 \%$ of groups were compared and corrected item-total correlations were performed.

Results: According to the first EFA results, a three-factor structure explaining $37.90 \%$ of total variance emerged. Since the factor loads of item 21 and 23 were below .30and item 22 was not theoreticallysupported by its factor, these items were excluded from the instrument.After removing these three items, EFA was performed again and also, a three-factor structure explaining $40.57 \%$ of total variance emerged.Taking content and theoretical background into account, the first factor was called as the BLDE, the second factor the BLDT, and the third factor the BTOOT. The BLDE comprised 10 items and explained $16.27 \%$ of total variance. The factor loads of the items in the BLDE varied between .54 and .76. The BLDT comprised 10 items and explained 14.12\% oftotal variance. The factor loads of the items in the BLDT varied between .42 and .70. The BTOOT comprisedseven items and explained $10.19 \%$ of total variance. The factor loads of the items in the BTOOT varied between .42 and .74. In order to understand whether all 27 items and a three-factor structure provide satisfactory indices of goodness of fit and to show further evidence for construct validity, CFA was performed. The findings obtained from CFA showed that the scale has satisfactory indices of goodness of fit. According to the results of concurrent validity,there is a positive relationship between the BLDE and mathematics achievement [ $n=315, r=.48, p<.001]$, and a negative relationship between the BLDT, the BTOOT, and mathematics achievement $[n=315, r=-$ $.25 p<.001, r=-.26, p<.001$ respectively]. These findings proved that the MOEBS has concurrent validity.The reliability of the MOEBS was checked by means of internal consistency and test-retest reliability.The internal consistency coefficients were found to be .84 for the BLDE, .81 for the BLDT, and .71 for the BTOOT. In order to check test- 
retest reliability, the scale was administered to 100 students twice in a two-week interval.In order to demonstrate consistency between the first and the second administration, the correlation between scores obtained from both two practices was calculated. Test-retest coefficients were found to be .96 for the BLDE, .95 for the BLDT and .95 for the BTOOT. Given that scales with a reliability coefficient of .70 and higher are regarded as reliable, it can be argued that the calculated reliability coefficients were high.In order to identifydiscriminatory and predictive power of the items, correcteditemtotal correlations werecalculated and both top and bottom $27 \%$ of groups were compared. Pearson Product Moment Correlation was used to determine corrected-item total correlation. To compare both top and bottom $27 \%$ of groups, independent-samples ttest was performed. In item analysis, it was found out that item-total correlations varied between .27 and .66 and differences between both top and bottom $27 \%$ of groups were significant for all items.

Discussion and Conclusions:In this research, the findings from statistical analyses of psychometric characteristics of the MOEBS revealed that the scale can be used as a valid and reliable instrument to measure students' epistemological beliefs related to mathematics. As a result of the present study which aims to contribute to the Turkish literature with the MOEBS, it can be argued that an instrument which has satisfactory psychometric characteristicsto measure students' beliefs on mathematical knowledge and mathematicslearning has been developed. In addition, due to the fact that the present study was carried out with merely high school students, it might be implied that the MOEBS is an instrument whose validity has been checked only with high school students. In this respect, future studies should check reliability and validity of the scale with different samples. 


\title{
Matematik Odaklı Epistemolojik İnanç Ölçeği (MOEIÖ): Geçerlik ve Güvenirlik Çalışması
}

\author{
Mustafa İLHAN*
}

Makale Gönderme Tarihi: 30 Kasım 2012

\author{
Bayram ÇETIN**
}

Makale Kabul Tarihi: 09 Mayıs 2013

\begin{abstract}
ÖZET:Bu araştırmada ortaöğretim öğrencilerinin matematik odaklı epistemolojik inançlarını ölçmeye olanak tanıyacak geçerli ve güvenilir bir ölçme aracının geliştirilmesi amaçlanmaktadır. Araştırma, 2012-2013 eğitimöğretim yılı güz yarıyılında Batman ve Diyarbakır illerinde toplam 406 ortaöğretim öğrencisinden oluşan iki ayrı çalışma grubu üzerinde yürütülmüştür. Araştırmada, ölçeğin kapsam ve görünüş geçerliği için uzman görüşüne başvurulmuş, yapı geçerliği için Açımlayıcı Faktör Analizi (AFA) ve Doğrulayıcı Faktör Analizi (DFA) uygulanmıştır. AFA sonucunda, toplam varyansın \%40.57'sini açıklayan, 27 madde ve üç faktörden oluşan bir yapı elde edilmiştir. Ortaya çıkan faktörler,Öğrenmenin Çabaya Bağlı Olduğuna İnanç (ÖÇBOİ), Öğrenmenin Yeteneğe Bağlı Olduğuna İnanç (ÖYBOİ) ve Tek Bir Doğrunun Var Olduğuna İnanç (TBDVOİ) olarak adlandırılmıştır. DFA'dan elde edilen bulgular, MOEİÖ'ye ilişkin 27 madde ve üç faktörlü yapının yeterli uyum indekslerine sahip olduğunu göstermiştir. ÖÇBOİ, ÖYBOİ ve TBDVOİ alt ölçeklerinin güvenirliği iç tutarlık ve test-tekrar test yöntemleriyle incelenmiş ve hesaplanan güvenirlik katsayılarının kabul edilebilir sınırlar içerisinde yer aldığı belirlenmiştir. Madde analizinden elde edilen bulgular, ölçekte yer alan maddelerin tamamının ayırt edici olduğunu göstermiştir. Bu bulgulara dayanarak, ölçeğin ortaöğretim öğrencilerinin matematik odaklı epistemolojik inançlarını ölçmek amacıyla kullanılabilecek geçerli ve güvenilir bir ölçme aracı olduğu söylenebilir.
\end{abstract}

Anahtar Sözcükler: matematik odaklı epistemolojik inanç, matematik odaklı epistemolojik inanç ölçeği, geçerlik, güvenirlik.

\section{Giriş}

İnançlar, bireyin tecrübeleri aracılı̆̆ıla şekillenen (Nespor, 1987; Pajares, 1992) tutum, davranış (Fischbein \& Ajzen, 1975; Hazır-Bıkmaz, 2002; Mansour, 2009; Olson, Roese, \& Zanna, 1996; Pintrich \& Schunk, 2002), motivasyon (Dweck \& Leggett, 1988) ve zihinsel süreçlerini etkileyen (Schommer, 1998), yaşamda karşılaştı̆ı her türlü olay, olgu, kişi ya da nesneyi nasıl algıladığını, anlamlandırdığını, ona karşı nasıl davrandığını belirleyen (Deryakulu, 2006; Fishbein \& Ajzen, 1975; Pajares, 1992) ve birey tarafından kuşku duyulmaksızın doğru olduğu varsayılan (Deryakulu, 2006; Koballa \& Crowley, 1985; Krows, 1999) içsel kabuller ya da önermeler olarak tanımlanmaktadır (Deryakulu, 2004; Oliver \& Koballa, 1992; Richardson, 2003). İnançların bireylerin düşünce ve davranışları üzerinde sahip olduğu bu güçlü belirleyici etki, eğitimcilerin öz yeterlik inancı, zekâya yönelik inanç, öğrenmeye yönelik inanç gibi birçok farklı inancı öğrenme ve öğretme süreçleri açısından dikkate almalarını zorunlu kılmaktadır (Deryakulu, 2006). Öğrenme-öğretme sürecinde dikkate alınması gereken inançlardan biri de epistemolojik inançlardır (Schommer, Crouse, \& Rhodes, 1992, Tsai, 2000).

Epistemolojik inançlar, bilginin doğası ve nasıl elde edildiği ile ilgili inançlar olup(Bendixen, Dunkle,\& Schraw, 1994; Hofer \& Pintrich, 1997, Perry, 1981; Schommer, 1994) öğrencilerin akademik performanslarını (Hofer, 2000; Rukavina \& Daneman, 1996; Ryan, 1984, Schraw, Bendixen, \& Dunkle, 2002), öğrenme

\footnotetext{
*Araş. Gör., Dicle Üniversitesi, mustafailhan21@gmail.com

*** Doç. Dr., Gaziantep Üniversitesi, bcetin27@gmail.com
} 
yaklaşımlarını (Cano, 2005; Phan, 2008),motivasyonlarını (Buehl \& Alexander, 2005) biliş ve bilişüstü stratejilerini (Paulsen \& Feldman, 1999) ve problem çözme becerilerini (Aksan \& Sözer, 2007; Bendixen \& Schraw, 2001) etkilemektedir.

Epistemolojik inançlar, ilk olarak Perry (1970) tarafindan incelenmiştir. Perry (1970),üniversitede öğrenim gören erkek öğrencilerin epistemolojik inançlarını boylamsal olarak incelediği araştırma sonucunda, epistemolojik inançların dört temel inanç çerçevesinde ilerlediğini rapor etmiştir. Perry (1970) tarafından ortaya konulan bu rapor, epistemolojik inançların gelişimine ilişkin ileri sürülen ilk model olma özelliği taşımaktadır. $\mathrm{Bu}$ modele göre, epistemolojik inançlar; ikicilik (dualism), çoğulculuk (multiplism), görecelilik (relativism) ve bağlılık (commitment) olmak üzere gelişimsel bir seyir izleyen dört düzeyden oluşmaktadır. Bu düzeylerden ilki, bilginin doğru/yanlış şeklinde mutlak gerçeklerden oluştuğu ve uzmanlar tarafından bireylere aktarılabildiği inancını yansıtan ikiciliktir. İkicilikten sonra, kişisel görüşlerin ve mutlak doğruların birleşiminden meydana gelen çoğulculuk düzeyi yer almaktadır. Çoğulculuk, birtakım mutlak doğruların olduğunu, bununla birlikte bazı şeylerin kesin olarak bilinemeyeceği inancını yansıtmaktadır. Perry(1970)'in modeline göre, epistemolojik inançların gelişimine ilişkin üçüncü düzey, bireylerin bilgiyi bireysel olarak yapılandırdığı inancını yansitan göreceliliktir. Göreceliliğin temelinde, doğruların bireylerin kişisel tecrübeleri ve yorumları ile ilişkili olduğu, bu nedenle mutlak doğruların bulunmadığı ve asla olmayacağı anlayışı yatmaktadır. Perry (1970) tarafindan öne sürülen modelin son düzeyini bağlılık oluşturmaktadır. Bağl1lık düzeyinde, göreceli düşünme devam etmekle beraber, bazı inançlar diğerlerinden daha değerli görülmekte ve bu inançlara esnek bir biçimde inanılmaktadır.

Perry’nin çalışmasının yalnızca üniversitede öğrenim gören erkek katılımcılar ile sinırlı tutulması, Belenky, Clinchy, Goldberger ve Tarule (1986) tarafindan bir sinırlılık olarak yorumlanmıştır. Belenky ve diğerleri (1986), bu sınırlılığın aşılabilmesi için gerçekleştirdikleri çalışmada, akademik geçmişi olan ve olmayan bayan katılımcılardan oluşan 135 kişilik bir gruba ahlâki, bilişsel ve kimlik gelişimini yansıtan açık uçlu sorular yöneltmişlerdir. Elde edilen verilerin analizi sonucunda, epistemolojik inançların gelişimine ilişkin Perry (1970) tarafından önerilen modele benzer bir sınıflama yapılmıştır. Bu sınıflamaya göre, epistemolojik inançlar; sessizlik (silence), kabul edilen bilgi (received bilgi), öznel bilgi (subjective), işlemsel bilgi (procedural) ve yapılandırılmış bilgi (constructed) olmak üzere beş düzeyli bir yapıya sahiptir. Sessizlik düzeyinde bireyler sessiz ve pasif bir duruş sergiler. Kabul edilen bilgi düzeyi, Perry (1970) tarafından öne sürülen ikiciliğe benzemektedir. Bireyler bu düzeyde, bilginin kesin ve mutlak olduğuna inanır ve bilgiyi uzman otoritesinden alan bir konumdadırlar. Öznel bilgi düzeyi, Perry(1970)’in modelindeki çoğulculuğa karş1lık gelmektedir. Bireyler bu düzeyde, bilgiye ilişkin kişisel ve öznel bir bakış açısına sahiptirler. İşlemsel bilgi düzeyi, Perry (1970) tarafından görecelilik olarak ifade edilen düzeye karşılık gelmektedir. Bireyler bu düzeyde, bilgiye ilişkin bağımsız, nesnel ve eleştirel bir bakış açısına sahiptirler. Yapılandırılmış bilgi düzeyi ise, Perry (1970) tarafından bağlılık 
olarak ifade edilen düzeye benzemektedir. Bu düzeyde bireyler, bilginin yapılandırıldığı ve bu yapılandırma sürecinde bireyin aktif bir rol aldığı inancına sahiptiler.

Perry (1970) ve Belenky ve diğerleri (1986) tarafindan epistemolojik inançlara ilişkin ileri sürülen düzeylere benzer bir diğer sınıflama, Baxter Magolda (1992) tarafından yapılmıştır. Baxter Magolda, 51'i bayan ve 50'si erkek olmak üzere toplam101 üniversite öğrencisi ile beş yıl süren boylamsal bir çalışma gerçekleştirmiştir. Çalışma kapsamında, her yıl öğrencilerle, epistemolojik inançlarını yansıtan kısa cevaplı ve açık uçlu sorulardan oluşan görüşmeler yapılmıştır. Çalışmada sonucunda, epistemolojik inançlar; kesinlik (absolute), geçiş (transitional), bağımsız (independent) ve bağlamsal (commitment) olarak adlandırılan dört boyut ile açıklanmıştır. Bilginin kesinliğine inananlar, tüm bilgilerin mutlak olduğu, uzmanların tüm doğruları bildiği, bireyin görevinin uzmanlar tarafından aktarılan bilgileri ezberlemek olduğu şeklinde bir anlayışa sahiptirler. Bilginin geçişliğine inananlar, uzmanların her şeyi bilmediklerini, bilginin belirsizliğini ve kesin olmadığını anlamaya başlarlar. Bilginin bağımsızlığına inananlar, bilginin büyük bir bölümünün kesin olmayan içeriklerden oluştuğu ve uzmanların bilginin tek kaynağ 1 olmadığı şeklinde bir anlayışa sahiptirler. Bağlamsal bilgiye inanlar, bilginin doğasında kesinlik olmadığı anlayışına sahip olmakla birlikte, ele alındığı içeriğe bağlı olarak bazı bilgilerin diğerlerinden daha değerli olabileceğini düşünürler.

Perry (1970), Belenky ve diğerleri (1986) ve Baxter Mogalda (1994) tarafından öne sürülen modellerde, epistemolojik inançlar, bilginin doğası ile ilgili inançlar olarak ele alınmıştır. Schommer (1990), epistemolojik inançları bilginin doğası ile ilgili inançlarla sınırlayan bu modellerin, öğrenmenin doğası hakkındaki inançları açıklamada yetersiz kaldığını ifade etmiştir. Bu yetersizliğin giderilebilmesi için, Schommer (1990) epistemolojik inançları, bilginin doğası ve öğrenmenin doğası hakkındaki inançlardan oluşan bir inanç sistemi olarak kavramsallaştırmıştır. Bilginin doğası ile ilgili inançlar bilginin yapısı, bilginin kesinliği, bilginin kaynağı boyutlarından meydana gelirken; öğrenmenin doğası ile ilgili inançlar öğrenme yeteneği ve öğrenme hızı boyutlarından oluşmaktadır. Bilginin yapısı ile ilgili gelişmemiş epistemolojik inançlara sahip bireyler bilginin basit olduğunu düşünürken, bilginin yapısı ile ilgili gelişmiş epistemolojik inançlara sahip bireyler bilginin karmaşık bir yapıya sahip olduğuna inanırlar. Bilginin kesinliği ile ilgili gelişmemiş epistemolojik inançlara sahip bireyler, bilginin mutlak olduğunu düşünürken; bilginin kesinliği ile ilgili gelişmiş epistemolojik inançlara sahip bireyler bilginin değişebilir bir yapıya sahip olduğuna inanırlar. Bilginin kaynağı ile ilgili gelişmemiş epistemolojik inançlara sahip bireyler, bilginin uzmanlar tarafından aktarıldığını düşünürken; bilginin kaynağı ile ilgili gelişmiş epistemolojik inanca sahip bireyler bilginin birey tarafından yapılandırıldığına inanırlar. Öğrenme yeteneği ile ilgili gelişmemiş epistemolojik inanca sahip bireyler öğrenme yeteneğinin doğuştan gelen değiştirilemez bir özellik olduğuna inanırken; öğrenme yeteneği ile ilgili gelişmiş epistemolojik inanca sahip bireyler öğrenme yeteneğinin geliştirilebilir bir özellik olduğuna inanırlar. Öğrenme hızı ile ilgili gelişmemiş epistemolojik inanca sahip bireyler, öğrenmenin hemen meydana geldiği ve hemen gerçekleşmeyen öğrenmelerin 
bir daha gerçekleşmeyeceği inancına sahipken; öğrenme yeteneği ile ilgili gelişmiş epistemolojik inanca sahip bireyler öğrenmenin yavaş yavaş gerçekleştiğini düşünürler. Schommer (1990), epistemolojik inançlar ile ilgili belirlediği kavramsal çerçeveye dayanarak epistemolojik inançları ölçmeye olanak tanıyacak bir ölçek geliştirmiştir. Geliştirdiği ölçeğin geçerliğini incelemek üzere uyguladığ 1 faktör analizi sonucunda, beş boyutlu teorik yapıdan farklı olarak 63 madde ve dört faktörden meydana gelen bir yapı elde etmiştir. Schommer(1994)'e göre, epistemolojik inançlar az ya da çok birbirinden bağımsızdır ve epistemolojik inançlara ilişkin farklı boyutlar eş zamanlı olarak gelişmeyebilir. Örneğin, bir birey bilginin yapısı ile ilgili gelişmiş epistemolojik inançlara sahip iken, bilginin kesinliği ile ilgili gelişmemiş epistemolojik inançlara sahip olabilir. Bir başka deyişle, bilginin karmaşık ve iç içe geçmiş olduğuna inanan bir birey aynı zamanda bilginin asla değişmeyeceğine de inanabilir. Dolayısıyla bireyin epistemolojik inançlarının anlaşılabilmesi için epistemolojik inanç ölçeğinin farklı boyutlarından alınan puanların ayrı ayrı değerlendirilmesi gerekmektedir.

Schommer (1990) tarafından geliştirilen epistemolojik inanç ölçeği daha sonra birçok araştırmacı tarafından kullanılmış ve ölçeğin geçerliği farklı örneklemler üzerinde test edilmiştir (Jehng, Johnson, \& Anderson, 1993; Schraw, Bendixen, \& Dunkle, 2002; Wood \& Kardash, 2002). Epistemolojik inanç ölçeğinin Türk kültürüne uyarlaması ise, Deryakulu ve Büyüköztürk (2002, 2005) tarafindan yapılmıştır. Uyarlama çalışmasından edilen bulgular, epistemolojik inanç ölçeğinin Türkçe formunun Öğrenmenin Çabaya Bağlı Olduğuna İnanç (ÖÇBOI), Öğrenmenin Yeteneğe Bağlı Olduğuna İnanç (ÖYBOİ) ve Tek Bir Doğrunun Var Olduğuna İnanç (TBDVOİ) şeklinde üç boyutlu bir yapıya sahip olduğunu göstermiştir. Epistemolojik inançların şekillenmesinde kültürel özellikler önemli etkiye sahip olduğundan (Buehl \& Alexander, 2006; Chan \& Elliot, 2004; Schommer, 2004) Türk kültüründeepistemolojik inançlar ile ilgili yapılan birçok araştırmada (Başçiftçi-Güleç, Akdoğan, \&Koç, 2011; Demirci, Türel, \&Özmen, 2010; Eren, 2006; Hacıömeroğlu, 2011; Özşeker, Canpolat, \&Yıldız, 2011; Yılmaz, 2007) epistemolojik inanç ölçeğinin Türkçeye uyarlanması sonucu ortaya çıkan ÖÇBOİ, ÖYBOİ ve TBDVOİ boyutları temele alınmıştır.

Epistemolojik inançların boyutlarıyla birlikte, araştırmacıların epistemolojik inançlara ilişkin farklı görüşlere sahip olduğu bir diğer konu epistemolojik inançların genel mi yoksa alan odaklı mı olduğuyla ilgilidir (Buehl \& Alexander, 2002; Eynde, Corte,\& Verschaffel, 2006; Gill, Ashton,\& Algina, 2004; Hammer, 1994; Limon, 2006; Stockon, 2010). Örneğin, Schommer ve Walker (1995) epistemolojik inançların bir alana özgü olmasından ziyade, farklı alanlara genellenebileceğini ifade ederken; Ruddick (1996), Calderhead (1996), Hofer ve Pintrich (1997), Mori (1997) ve Buehl ve Alexander (2004) epistemolojik inançların alana özgü olduğunu savunmuştur. Bu durum, epistemolojik inançların genel mi yoksa alan odaklı mı ele alınmasının daha doğru olacağını ortaya koymak üzere grup içi ve gruplar arası desende çeşitli araştırmaların yapılmasına neden olmuştur (Muis, Bendixen,\& Haerle, 2006). Epistemolojik inançlarla ilgili olarak grup içi desende gerçekleştirilen araştırmalarda, öğrencilerin genel ve alan odaklı epistemolojik inançları arasında anlamlı farklılıkların 
bulunduğu belirlenmiştir (Beers, 1988; Buehl, Alexander,\& Murphy, 2002; Hofer, 2000; Mori, 1999; Roth \& Roychoudhury, 1994; Schoenfeld, 1989). Benzer şekilde, epistemolojik inançlar ile ilgili gruplar arası desende gerçekleştirilen çalışmalar, farklı alanlarda öğrenim gören öğrencilerin genel epistemolojik inançları arasında anlamlı farklılıklar bulunduğunu göstermiştir (Aypay, 2011; Can \&Arabacıŏlu, 2009; Deryakulu \&Büyüköztürk, 2005; Enman \& Lupart, 2000; Eren, 2006;Jehng, Johnson, \& Anderson, 1993; Kurt, 2009; Paulsen\& Wells, 1997; Strobel, Cernusca, \& Jonassen, 2004). Söz konusu araştırmalardan elde edilen bulgular, genel epistemolojik inançların yanı sıra alan odaklı epistemolojik inançların da dikkate alınması gerektiği yönündeki inançları güçlendirmiştir. Buna bağlı olarak, farklı alanlara yönelik epistemolojik inançları belirlemek amacıyla kullanılabilecek alan odaklı epistemolojik inanç ölçeklerinin geliştirilmesi ihtiyacı doğmuştur. Bu ihtiyaç, değişik alanlara yönelikçeşitli alan odaklı epistemolojik inanç ölçeklerinin geliştirilmesine kaynaklık etmiştir.Hofer (2000) tarafından yapılan araştırmada, psikoloji ve fen bilimleri alanlarına, Buehl, Alexander ve Murphy (2002) tarafından yapılan araştırmada matematik ve tarih alanlarına, Schommer, Duell ve Barker (2003) tarafindan yapılan araştırmada matematik, sosyal bilimler ve iş alanlarına, Eren (2006) tarafından yapılan araştırmada fizik, kimya, kamu yönetimi, iktisat, özel eğitim ve Türkçe eğitimi alanlarına, WalkerWheeler (2007) ve Tang (2010) tarafından yapılan araştırmalarda matematik alanına yönelik epistemolojik inanç ölçekleri geliştirilmiştir.

Literatürdeki, alan odaklı epistemolojik inanç ölçekleri incelendiğinde, fen bilimleri ve sosyal bilimler alanlarına yönelik hem farklı kültürlerde (Buehl, Alexander, \& Murphy, 2002; Hofer, 2000; Schommer-Aikins, Duell,\& Barker, 2003) hem de Türk kültüründe (Eren, 2006) çeşitli ölçme araçlarının bulunduğu görülmektedir. Diğer taraftan, farklı kültürlerde matematik alanına yönelik epistemolojik inançları belirlemek amacıyla çok sayıda ölçek (Buehl, Alexander, \& Murphy,2002; Schommer, Duell,\& Barker, 2003; Tang, 2010; Walker-Wheeler, 2007) bulunmasına rağmen, Türk kültüründe öğrencilerin matematik odaklı epistemolojik inançları belirlemek amacıyla kullanılabilecek bir ölçme aracına rastlanmamıştır. Oysa matematik odaklı epistemolojik inançlar matematik öğreniminin önemli bir bileşeni olup (Ertekin, Dilmaç, Yazıcı, \&Peker, 2010), matematik odaklı epistemolojik inançların belirlenmesi; öğrenme sürecinde öğrencileri desteklemek için neler yapılması, öğrenme ortamlarının nasıl düzenlenmesi ve matematik öğretim programları hazırlanırken nelere dikkat edilmesi gerektiğine rehberlik edebilir (Abedalaziz \& Akmar, 2012). Bu bağlamda, öğrencilerin matematik alanına yönelik epistemolojik inançlarını belirlemek amacıyla kullanılabilecek bir ölçeğin Türk kültürüne kazandırılması önem arz etmektedir. Matematik odaklı epistemolojik inanç ölçeğinin Türk kültürüne kazandırılabilmesi için, alanyazındaki genel ve alan odaklı epistemolojik inanç ölçeklerinden hareketle matematik odaklı epistemolojik inanç ölçeğinin geliştirilmesi veya farklı kültürlerde geliştirilen matematik odaklı epistemolojik inanç ölçeklerinden herhangi birinin Türkçeye uyarlanması şeklinde iki farklı yol takip edilebilir. Bununla birlikte, epistemolojik inançların kültürel faktörlerin etkisiyle şekillendiği (Buehl \&Alexander, 2006; Chan \& Elliot, 2004; Schommer, 2004) göz önüne alındığında, farklı kültürde 
geliştirilen matematik odaklı epistemolojik inanç ölçeklerinden herhangi birini Türkçeye uyarlamak yerine genel ve alan odaklı epistemolojik inanç ölçeklerinden yola çıkarak bir ölçek geliştirmenin daha doğru bir tercih olacağı düşünülmüştür. $\mathrm{Bu}$ kapsamda araştırmada, öğrencilerin matematik odaklı epistemolojik inançlarını ölçmeye olanak tanıyacak geçerli ve güvenilirbir ölçme aracının geliştirilmesi amaçlanmaktadır.

\section{Yöntem}

\section{Araştırma Grubu}

Araştırma, 2012-2013 eğitim-öğretim y1lı güz yarıyılındaortaöğretim öğrencilerinden oluşan iki farklı çalışma grubu üzerinde yürütülmüştür. Birinci çalışma grubu, Batman il merkezindeki beş farklı liseden 236's1 (\%56.32) kız ve 183'ü (\%43.68) erkek olmak üzere toplam 419 öğrenciden oluşmaktadır. Ancak, çok sayıda cevapsız maddenin bulunması, bir madde için birden fazla seçeneğin işaretlenmiş olmasıveya ölçme aracında yer alan olumlu-olumsuz tüm maddelere aynı cevabın verilmiş olmasından dolayı maddelerin okunmadan ölçme aracının doldurulduğu izlenimini uyandıran veriler, veri setinin dişında tutulmuştur. Bu nedenle, toplamda 104 (54 kız ve 50 erkek) öğrenciye ait veri, istatistiksel analizler gerçekleştirilmeden önce veri setinden çıkarılmıştır. Böylelikle birinci çalışma grubunda, 182'si kız (\%57.80) ve 133’ü erkek olmak üzere (\%42.20) toplam 315 öğrenciye ait veri kalmıştır. Bu öğrencilerin 122'si (\%38.70) fen lisesinde, 154'ü (\% 48.90) meslek lisesinde ve 39’u (\% 12.40) genel lisede öğrenim görmektedir. Ayrıca, öğrencilerin 166’sı (\%52.70) 9. sinıfa, 38'i (\%12.10) 10. sinıfa, 76's1 (\%24.10) 11. sinıfa ve 35'i (\% 11.10) 12. sinıfa devam etmektedir. Ölçeğin yapı geçerliği, uyum geçerliği, iç tutarlık güvenirliği ve madde analizleri bu gruptan elde edilen veriler üzerinde gerçekleştirilmiştir. İkinci çalışma grubu ise, Diyarbakır ili Silvan ilçesi Anadolu Öğretmen Lisesi’nde öğrenim gören 47’si (\%44.34) kız ve 59’si erkek (\%55.66) olmak üzere toplam 106 öğrenciden oluşmaktadır.Bu gruptaki öğrencilerin 56’sı (\%52.83) 9.sınıfa ve 50’si (\%47.17) 10.sınıfa devam eden öğrencilerdir. Ölçeğin test-tekrar test güvenirliği bu gruptan elde edilen veriler üzerinden hesaplanmıştır.Test-tekrar test güvenirliğine yönelik istatistiksel analizler gerçekleştirilmeden önce, test-tekrar test güvenirliği için iki hafta ara ile gerçekleştirilen iki uygulamadan herhangi birine katılmayan 15 (8 kız ve 7 erkek) öğrenciye ait veriler, veri setinden çıkarılmıştır. Bu işlemin ardından, test-tekrar test güvenirliğine yönelik gerçekleştirilen her iki uygulamada da yer alan 91 öğrenciye ait veri üzerinden ölçeğin test-tekrar test güvenirlik katsayısı hesaplanmıştır.

\section{İşlem}

Matematik Odaklı Epistemolojik İnanç Ölçeği (MOEIÖ)'nün geliştirilmesi sürecinde, Cronbach (1984), Crocker ve Algina (1986) ve DeVellis (2003) tarafindan önerilen adımlar takip edilmiştir. Buna göre, ölçek geliştirme sürecinde izlenen basamaklar aşağıda özetlenmiştir. 


\section{Ölçekten alınan puanlar ile ölçülecek özellik/özelliklerin} belirlenmesi.MOEï̈ ile öğrencilerin matematiksel bilginin ve matematik öğrenmenin doğasına ilişkin inançlarının ölçülmesi amaçlanmaktadır.

\section{Ölçülecek yapıyı temsil eden davranışların tanımlanması.MOEIÖ} geliştirilirken Schommer (1990) tarafindan geliştirilip Deryakulu ve Büyüköztürk (2002, 2005) tarafindan Türkçeye uyarlanan genel epistemolojik inanç ölçeğindeki ÖÇBOI, ÖYBOİ ve TBDVOİ boyutları temele alınmıştır. ÖÇBOİ ile matematik öğrenme yeteneğinin bireysel tecrübeler ile ne ölçüde geliştirilebileceğine ilişkin inançların ölçülmesi amaçlanmaktadır.ÖYBOİ boyutu ile matematik öğrenme yeteneğinin doğuştan gelen, değişmez bir özellik olduğuna ilişkin inançların ölçülmesi hedeflenmektedir.TBDVOİ boyutuyla ise, matematiksel bilginin kesinliği ve değişmezliğine ilişkin inançların ölçülmesi amaçlanmaktadır.

Ölçekte yer alacak maddelerin yazılması.MOEIÖ'de yer alacak maddelerin yazımında, genel epistemolojik inanç ölçekleri (Deryakulu\&Büyüköztürk, 2002, 2005; Schommer, 1990) ile alan odaklı epistemolojik inanç ölçeklerinden (Abedalaziz \& Akmar, 2012; Buehl, Alexander,\& Murphy, 2002; Eren, 2006; Hofer, 2000; Steiner, 2007; Stockton, 2010; Walker-Wheeler, 2007)yararlanılmış;matematik öğretmenlerinin, matematik eğitimi ve eğitimi bilimleri uzmanlarının görüşlerine başvurulmuştur.Madde havuzu, ölçek geliştirme sürecinde temele alınan ÖÇBOİ, ÖYBOİ ve TBDVOİ boyutlarından yola çıkılarak oluşturulmuştur. ÖÇBOI boyutunu yansıtan 11 madde, ÖYBOİ boyutunu yansitan 10 madde ve TBDVOİ boyutunu yansitan 14 madde yazılarak toplamda 35 maddeden oluşan bir madde havuzu elde edilmiştir.Ölçekte yer alan ifadeler için Kesinlikle Katılyyorum (5), Kattllyorum (4), Kararsızım (3), Katılmıyorum (2) ve Kesinlikle Katılmıyorum (1) şeklinde beşli Likert tipi bir derecelendirme kullanılmıştır.

Taslak ölçme aracında yer alan maddeler için uzman görüşü alınması ve ölçeğin yeniden gözden geçirilmesi.MOEİÖ'nin kapsam ve görünüş geçerliğini sağlamak için birölçme değerlendirme uzmanı, üçeğitim programları ve öğretim uzmanı ve ikimatematik eğitimi uzmanı olmak üzere toplam altıuzmandan görüş alınmıştır.Bir konu ile ilgili kapsamın belirlenmesi, bir yargılamayı gerektirdiğinden uzmanlar ile ölçme aracını geliştiren kişilerin ortak tanımlarının olması gereklidir (Tavşancıl, 2010).Özellikle, birden fazla alt ölçekten oluşan çok boyutlu ölçme araçlarında ölçülmek istenen yapının farklı boyutlarını belirlemek amacıyla yazılan maddelerin, yer almaları beklenen boyut ile ilgili olup olmadığının uzmanlartarafından değerlendirilmesi gerekir (DeVellis, 2003). Bu gerekliliğe bağlı olarak, uzmanlardan, ölçeği, ölçek maddelerinin hazırlanması sürecinde araştırmacılar tarafından temele alınan ÖÇBOİ, ÖYBOİ ve TBDVOİ boyutları 1şı̆ğında değerlendirmeleri istenmiştir. Uzmanlardan gelen görüşler sonucunda, ÖÇBOİ boyutuna yönelik olarak hazırlanan 11 maddeden birive TBDVOİ boyutuna yönelik olarak hazırlanan 14 maddeden dördü ölçekten çıkarılmıştır. $\mathrm{Bu}$ işlemin ardından, ölçekte ÖÇBOİ boyutunu yansıtan 10 madde, ÖYBOİ boyutunu yansitan 10 madde ve TBDVOİ boyutunu yansitan 10 madde olmak 
üzere toplam 30 madde kalmıştır. Uzmanların ölçekten çıkarılmasını önerdiği beşmaddenin ölçtüğü özelliği belirlemeye yönelik farklı maddeler ölçekte yer aldığından, söz konusu maddelerin ölçme aracından çıkarılması ölçeğin kapsam geçerliğine zarar vermemiştir. Ayrıca, uzmanlardan alınan görüşler doğrultusunda, hazırlanan bazı maddelerin ifade ediliş şekillerinde değişikliğe gidilmiştir. Örneğin, uzmanlardan ikisi, TBDVOİ'yi yansıtan “Matematik alanındaki konular tartışmaya açık değildir" maddesinde yer alan konular ifadesi yerine doğrular ifadesinin kullanılmasının daha uygun olacağını belirtmişlerdir. Bunun üzerine, bu madde "Matematik alanındaki doğrular tartışmaya açık değildir" şeklinde yeniden ifade edilmiştir. Uzman görüşlerinden yola çıkılarak, ölçek maddelerinde gerekli değişiklikler yapıldıktan sonra, ölçme aracının dil açısından anlaşılabilirliğini sağlamak amacıyla, üçTürk Dili uzmanından görüş alınmıştır. Uzmanların yazım kuralları ve noktalama işaretlerinin kullanımı ile ilgili görüşleri doğrultusundaölçek maddeleri gözden geçirilmiştir.

\section{Uygulama öncesinde küçük bir grup üzerinde ön uygulama} yapılması.MOEİÖ'de yer alan maddelerin anlaşılırlığı ve ölçeğin uygulama süresi hakkında geri bildirim almak için, 13 lise öğrencisi (altıkız ve yedierkek) üzerinde ön uygulama yapılmıştır. MOEİÖ’yü cevaplandıran öğrencilerle uygulamanın ardından görüşmeler gerçekleştirilmiştir.Görüşmelerdeöğrencilerin ölçekte yer alan maddelerin anlaşılırlığına ilişkin fikirleri alınmıştır. Öğrencilere ayrıca, ölçeğin amacını, ölçekteki madde sayısını ve ölçeğin nasıl doldurulması gerektiğini belirtmek üzere ölçeğin başında sunulan yönerge hakkındaki düşünceleri sorulmuştur. Yapılan görüşmeler, ölçek için hazırlanan yönergede ve ölçek maddelerinde herhangi bir değişikliğe ihtiyaç duyulmadığını göstermiştir.Ölçeğin yaklaşık uygulama süresi olarak, ön uygulamanın gerçekleştirildiği 13 kişilik grupta, ölçeği en kısa sürede dolduran öğrenci ile en uzun sürede dolduran öğrencinin harcadıkları sürelerin ortalaması belirlenmiştir.Bu süreçlerden sonra ölçek geniş bir çalışma grubu üzerinde uygulamaya hazır hâle gelmiştir.

\section{Ölçeğin temsil özelliği yüksek geniş bir örnekleme uygulanması ve ölçeğin psikometrik özelliklerini belirlemeye yönelik analizlerin} gerçekleştirilmesi.Uygulamalar, ölçeğin psikometrik özelliklerini ortaya koymak için yeterli katılımcıdan oluşan bir araştırma grubu üzerinde gerçekleştirilmiştir.Ölçek, sınıf ortamında öğrencilere uygulanmıştır. Uygulama sırasında, araştırmacının sınıfta bulunmasına özen gösterilmiştir. Uygulamaya başlamadan önce, öğrenciler araştırmanın amacı hakkında bilgilendirilmiştir. Öğrencilere, elde edilen verilerin yalnızca araştırmanın amacı için kullanılacağı, başka herhangi bir kurum ya da kişiyle paylaşılmayacağı belirtilmiştir. Yine uygulamadan önce, öğrencilere araştırmaya katılımın zorunlu olmadığı hatırlatılarak araştırma grubunun yalnızca gönüllü katılımcılardan oluşması sağlanmıştır. Öğrencilere, ölçeği nasıl doldurmaları gerektiği anlatılmış, maddelerin doğru ya da yanlışcevaplarınınolmadığı, verilen ifadeye dayalı olarak kendileri için uygun olan seçeneği işaretlemeleri istenmiştir. Öğrenciler, 
birbirlerini etkilememeleri konusunda uyarılmıştır. Ayrıca, ölçeği içtenlikle yanıtlamalarının geçerli ve güvenilir sonuçlar elde edilebilmesi için son derece önemli olduğu araştırmacı tarafindan katılımcılara ifade edilmiştir.Uygulama süresince araştırmacının sınıf ortamında bulunması, ölçeğin uygulanması sırasında karşılaşılan problemlere doğrudan müdahale etme imkânı tanımıştır. Örneğin, ölçekte uyarı olarak belirtilmesine ve uygulamadan önce hatırlatılmasına rağmen, ölçeğin arka sayfasını doldurmayı unutan öğrencilere gerekli hatırlatmalar yapılabilmiştir.Veri toplama sürecinin ardından ölçeğin psikometrik özelliklerini belirlemeye yönelik istatistiksel analizler gerçekleştirilmiştir.

Ölçeğin nasıl puanlanacağına ve nasıl yorumlanacağına ilişkin bir yönergenin hazırlanması.MOEİÖ'nün alt boyutlarından alınabilecek puanların hangi aralıkta değişebileceği belirtilmiştir. Ayrıca, ölçeğin alt boyutlarından alınan yüksek ve düşük puanların nasıl yorumlanması gerektiği açıklanmıştır.

\section{Geçerlik, güvenirlik ve madde analizine yönelik olarak gerçekleştirilen} istatistiksel analizler.MOEİÖaraştırma grubuna uygulandıktan sonra, ölçeğin psikometrik özelliklerini ortaya koymak için istatistiksel analizler gerçekleştirilmiştir. İlk olarak ölçeğin yapı geçerliği incelenmiş, bu amaçla Açımlayıcı Faktör Analizi (AFA) ve Doğrulayıcı Faktör Analizi (DFA) uygulanmıştır. MOEİÖ’nün uyum geçerliği kapsamında, MOEİÖ'nün alt boyutları ile öğrencilerin matematik başarıları (bir önceki yıla ait karne notları) arasındaki korelasyon hesaplanmıştır. MOEİÖ'nün güvenirliği, iç tutarlık ve test-tekrar test yöntemleriyle incelenmiştir. MOEİÖ'de yer alan maddelerin ayırt edicilik düzeylerini saptamak amacıyla düzeltilmiş madde toplam korelasyonu hesaplanmış ve \%27'lik alt-üst grup karşılaştırmalarına yer verilmiştir. Araştırmanın verileri SPSS 20.0 ve LISREL 8.54 paket programları kullanılarak analiz edilmiştir.

\section{Bulgular}

\section{Yapı Geçerliği}

Bu çalışmada, MOEİÖ’nün yapı geçerliği kapsamında AFA ve DFA uygulanmıştır.

Açımlayıcı faktör analizi (AFA).AFA gerçekleştirilmeden önce veri setinin faktör analizine uygun olup olmadığının incelenmesi gerekir. Örneklem büyüklüğü, bu incelemede ilk sırada yer almaktadır (Akbulut, 2010). Faktör analizi çalışmalarında yer alması gereken katılımcı sayısı konusunda farklı araştırmacılar tarafından değişik öneriler getirilmiştir. Cattell (1978), faktör analizi çalışmalarında, ölçekteki madde sayısının üçile altıkatı kadar katılımcının çalışma grubuna dâhil edilmesini önermekte ve faktör analizi için 200 katılımcıyı kabul edilebilir, 500 katılımcıyı ise oldukça iyi bir sayı olarak ifade etmektedir. Hair, Anderson, Tatham ve Grablowsky (1979), faktör analizi için, ölçekte yer alan madde sayısının 20 katı kadar katılımcının çalışma grubuna dâhil edilmesini önermektedir. Gorsuch (1983) faktör analizi çalışmalarında ölçekte yer 
alan her madde için çalışma grubunda en az beşkatılımcının bulunması önermekte, bununla birlikte katılımcı sayısının 100'den az olmaması gerektiğini belirtmektedir (Cramer. 2003). Crowley ve Lee (1992) faktör analizi için 100 katılımcıyı yetersiz, 200'ü ortalama, 300'ü iyi, 500'ü çok iyi ve 1000 katılımcıyı mükemmel olarak nitelendirmektedir(Akbulut, 2010).Ferguson ve Cox (1993) faktör analizi çalışmalarında ölçüt olarak alınması gereken katılımcı sayısının en az 100 olduğunu belirtmektedir. Kline (1994) ise, faktör analizinde güvenilir sonuçlar elde etmek için 200 kişilik örneklemin genellikle yeterli olacağını, faktör yapısının açık ve az sayıda olduğu durumlarda bu rakamın 100'e kadar indirilebileceğini, ancak büyük örneklemlerle çalışmanın daha uygun olacağını vurgulamaktadır. Faktör analizi için uygun örneklem büyüklüğü tahmininde farklı yaklaşımlar dikkate alındığında, literatürde yer verilen ölçütlerden en az ikisini karşılayacak bir büyüklüğe ulaşılması önerilmektedir (Çokluk, Şekercioğlu, \&Büyüköztürk. 2012). Bu ölçütlere göre, araştırmadaki katılımcı sayısının faktör analizi için yeterli olduğu söylenebilir. Verilerin faktör analizine uygun olup olmadığını belirlemek amacıyla yapılacak bir diğer işlem Kaiser-Mayer-Olkin (KMO) ve Barlett testlerinin gerçekleştirilmesidir. KMO, sıfır ile birarasında değişen değerler alabilmektedir. Kaiser (1974)'e göre0.5’in üzerindeki KMO değerleri kabul edilebilir değerlerdir (Field, 2009). Bununla birlikte, 0.5 ile 0.7 arasındaki KMO değerlerinin orta, 0.7 ile 0.8 arasındaki değerlerin iyi, 0.8 ile 0.9 arasındaki değerlerin çok iyi ve 0.9'un üzerindeki değerlerin ise mükemmel olduğu kabul edilmektedir (Hutcheson \& Sofroniou, 1999). Bu araştırmada, KMO değeri .811 bulunmuş ve Barlett testinin istatistiksel olarak anlamlı olduğu $\left(\chi^{2}=2613.891, s d=435\right)$ belirlenmiştir. Bu sonuca göre, verilerin faktör analizine uygun olduğu söylenebilir. $\mathrm{Bu}$ tespitin ardından AFA'da temel bileşenler yöntemi ve dik (varimax) döndürme sonucunda, toplam varyansın \%37.90'ını açıklayan üç faktörlü bir yapı elde edilmiştir. Genel epistemolojik inanç ölçeklerinde, ölçek boyutlarının birbirinden bağımsız olması (Deryakulu \&Büyüköztürk, 2002, 2005; Schommer, 1990), MOEİÖ’de de ölçek faktörleri arasında bir ilişki olmayacağını düşündürmüştür. Ölçek faktörlerinin birbirleriyle ilişkili olmayacağına yönelik bu öngörü nedeniyle AFA'da dik döndürme tekniği kullanılmıştır. AFA sonucunda elde edilen bulgular Tablo 1'de sunulmuştur. 
Tablo 1

MOEİ̈̈ AFA İlk Analiz Sonuçları

\begin{tabular}{|c|c|c|c|}
\hline Madde No & Faktör 1 & Faktör 2 & Faktör 3 \\
\hline MOEİÖ 1 & .748 & -.090 & .053 \\
\hline MOEİÖ 9 & .689 & -.001 & .214 \\
\hline MOEİÖ 2 & .628 & -.018 & .251 \\
\hline MOEİÖ 4 & .622 & -.067 & -.040 \\
\hline MOEİÖ 3 & .619 & .104 & .198 \\
\hline MOEİÖ 5 & .615 & -.184 & .219 \\
\hline MOEİÖ 7 & .577 & -.058 & -.141 \\
\hline MOEİÖ 8 & .571 & -.018 & -.066 \\
\hline MOEİÖ 6 & .569 & .079 & .165 \\
\hline MOEİÖ 10 & .565 & -.074 & -.190 \\
\hline MOEİÖ 22 & .445 & .125 & -.284 \\
\hline MOEİÖ 23 & .244 & 145 & -.108 \\
\hline MOEİÖ 17 & -.016 & .679 & .093 \\
\hline MOEİÖ 15 & -.023 & .661 & .183 \\
\hline MOEİÖ 19 & .106 & .645 & .063 \\
\hline MOEİÖ 14 & -.184 & .625 & .098 \\
\hline MOEİÖ 20 & -.165 & .625 & .169 \\
\hline MOEİÖ 18 & -.314 & .617 & .103 \\
\hline MOEİÖ 12 & -.141 & .611 & -.048 \\
\hline MOEİÖ 13 & .101 & .548 & -.020 \\
\hline MOEİÖ 11 & .113 & .498 & .004 \\
\hline MOEİÖ 16 & .208 & .429 & -.285 \\
\hline MOEİÖ 21 & . 183 & 290 & .236 \\
\hline MOEİÖ 27 & 198 & .164 & .704 \\
\hline MOEİÖ 24 & .151 & .109 & .679 \\
\hline MOEİÖ 25 & .018 & .082 & .561 \\
\hline MOEİÖ 26 & .051 & .154 & .559 \\
\hline MOEİÖ 28 & -.103 & -.112 & .557 \\
\hline MOEİÖ 30 & -.266 & -.097 & .455 \\
\hline MOEİÖ 29 & .083 & .236 & .380 \\
\hline
\end{tabular}

AFA'nın ilk sonuçlarına göre, 21. ve 23. maddeler faktör yükü .30'dan düşük olduğu için (Büyüköztürk, 2010; Costello \& Osborne, 2005; Martin \& Newell, 2004; Pallant, 2005; Schriesheim \& Eisenbach, 1995), 22. madde ise yer aldığı faktörle kuramsal olarak desteklenmediği için ölçme aracından çıkarılmıştır. Bu üç maddenin çıkarılmasından sonra, AFA tekrarlanmış ve toplam varyansın \%40.57'sini açıklayan üç faktörlü bir yapı elde edilmiştir. Faktörlerde toplanan maddelerin içerikleri ve kuramsal yapı dikkate alınarak birinci faktör ÖÇBOİ, ikinci faktör ÖYBOİ ve üçüncü faktör TBDVOİ olarak adlandırılmıştır. ÖÇBOİ alt ölçeği 10 maddeden oluşmakta ve toplam varyansın \%16.27'sini açıklamaktadır. Bu alt ölçekte yer alan maddelerin faktör yükleri .54 ile .76 arasında değişmektedir. ÖYBOİ alt ölçeği 10 maddeden oluşmakta ve toplam varyansın \%14.12'sini açıklamaktadır. Bu alt ölçekte yer alan maddelerin faktörü yükleri .42 ile .70 arasında sıralanmaktadır. TBDVOİ alt ölçeği yedi maddeden oluşmakta ve toplam varyansın \%10.19'unu açıklamaktadır. Bu alt ölçekte yer alan maddelerin faktör yükleri .42 ile .74 değişmektedir. MOEİÖ’nün açıkladığı varyans oranı ve faktör yüklerine ilişkin bulgular ise Tablo 2'de gösterilmiştir. 
Tablo 2

MOEIÖ Çıkarılan Maddelerin Ardından Tekrarlanan AFA Sonuçları

\begin{tabular}{|c|c|c|c|}
\hline 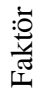 & Madde No & Maddeler & $\begin{array}{l}\text { Faktör } \\
\text { Yükü }\end{array}$ \\
\hline \multirow{11}{*}{$\begin{array}{l}\overline{0} \\
0 \\
0 \\
0\end{array}$} & MOEİÖ1 & $\begin{array}{l}\text { Bir öğrencinin matematiği ne kadar iyi öğrenebileceği ne kadar çaba harcadığına } \\
\text { bağlıdır. }\end{array}$ & .755 \\
\hline & MOEİÖ2 & $\begin{array}{l}\text { Ne kadar yetenekli olursanız olun, çaba harcamadan matematik alanında başarılı } \\
\text { olamazsınız. }\end{array}$ & .656 \\
\hline & MOEİÖ3 & Yalnızca çok çaba sarf eden kişiler iyi bir matematikçi olabilirler. & .653 \\
\hline & MOEİÖ4 & $\begin{array}{l}\text { İnsanların matematik başarılarındaki farklılık ortaya koydukları çabanın farklı } \\
\text { olmasından kaynaklanmaktadır. }\end{array}$ & .634 \\
\hline & MOEİÖ5 & Gerçekten çaba harcarsa her birey matematik öğrenebilir & .636 \\
\hline & MOEİÖ6 & Matematik alanındaki zor konuları yalnızca çok çaba sarf eden bireyler öğrenebilir. & .598 \\
\hline & MOEİÖ7 & $\begin{array}{l}\text { Matematik alanındaki bir konuyu hemen anlamayan bir öğrenci anlamak için çaba } \\
\text { sarf etmeyi sürdürmelidir. }\end{array}$ & .567 \\
\hline & MOEİÖ8 & $\begin{array}{l}\text { Matematik alanında çaba sarf etmeden bilgi sahibi olunamayacağını bilmek } \\
\text { matematik alanında başarılı olabilmenin ilk adımıdır. }\end{array}$ & .565 \\
\hline & MOEİÖ9 & Matematik alanındaki en başarılı insanlar en fazla çaba harcayan insanlardır. & .700 \\
\hline & MOEİÖ10 & Doğru çalışma becerilerini öğrenmek bireyin matematik yeteneğini geliştirebilir. & .540 \\
\hline & & Açıkladığı Varyans \% & 16.266 \\
\hline \multirow{11}{*}{ 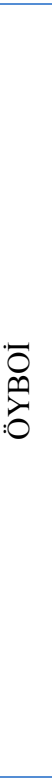 } & MOEİÖ11 & $\begin{array}{l}\text { İnsanlar yeni şeyler öğrenebilirler ancak sahip oldukları matematik yeteneğini } \\
\text { değiştiremezler }\end{array}$ & .502 \\
\hline & MOEİÖ12 & $\begin{array}{l}\text { Matematik alanında başarılı olan insanlar doğuştan matematik yeteneğiyle dünyaya } \\
\text { gelmiş olan kişilerdir }\end{array}$ & .613 \\
\hline & MOEİÖ13 & $\begin{array}{l}\text { İnsanların çoğu erken yaşlardan itibaren matematik alanında başarılı olup } \\
\text { olamayacaklarını bilirler }\end{array}$ & .552 \\
\hline & MOEİÖ14 & $\begin{array}{l}\text { Bir matematik problemini birkaç dakika içinde çözemeyen bir ögrenci ne kadar çaba } \\
\text { harcarsa harcasın muhtemelen problemi çözemeyecektir }\end{array}$ & .636 \\
\hline & MOEİ̈15 & Yalnızca matematik alanında yetenekli olan kişiler iyi bir matematikçi olabilirler & .662 \\
\hline & MOEİÖ16 & $\begin{array}{l}\text { İnsanların matematik başarılarındaki farklılık matematik yeteneklerinin farklı } \\
\text { olmasından kaynaklanmaktadır }\end{array}$ & .419 \\
\hline & MOEİ̈17 & $\begin{array}{l}\text { Matematik alanındaki zor konuları, yalnızca matematik alanında yetenekli olan } \\
\text { insanlar öğrenebilir }\end{array}$ & .698 \\
\hline & MOEIÖÖ18 & $\begin{array}{l}\text { Matematik yeteneği olmayan bir öğrencinin matematik öğrenmek için çaba } \\
\text { harcaması vakit kaybıdır }\end{array}$ & .620 \\
\hline & MOEİÖ19 & $\begin{array}{l}\text { Ne kadar çaba harcarsanız harcayın matematik alanındaki başarınızı bu alandaki } \\
\text { yetenekleriniz belirler }\end{array}$ & .634 \\
\hline & MOEİÖ20 & $\begin{array}{l}\text { Matematik alanında yetenekli olmayan bir öğrencinin bu alandaki başarılı olabilmek } \\
\text { için yapacak çok şeyi yoktur }\end{array}$ & .622 \\
\hline & & Açıkladığı Varyans \% & 14.115 \\
\hline \multirow{9}{*}{ 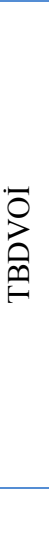 } & MOEİÖ24 & $\begin{array}{l}\text { Matematik alanında kuram (teori) haline gelmiş bir bilginin yanlış olması mümkün } \\
\text { değildir }\end{array}$ & .701 \\
\hline & MOEİÖ25 & Matematik alanındaki konular tartışmaya açık değildir & .558 \\
\hline & MOEİÖ26 & Matematik alanındaki her konu hakkında yalnızca tek bir doğru vardır & .576 \\
\hline & MOEİÖ27 & Matematik alanındaki doğrular değişmezdir & .735 \\
\hline & MOEİÖ28 & $\begin{array}{l}\text { Matematik alanında, bugün doğru olduğu düşünülen bir bilginin ilerleyen } \\
\text { zamanlarda yanlış olduğu anlaşılabilir }\end{array}$ & .557 \\
\hline & MOEİÖ29 & $\begin{array}{l}\text { Matematik alanındaki herhangi bir konu farklı bakış açılarıyla ele alınsa da o konuya } \\
\text { ilişkin ancak tek bir doğru olabilir }\end{array}$ & .424 \\
\hline & MOEİ̈30 & $\begin{array}{l}\text { Matematik alanında hakkında en fazla bilgiye sahip olunun konuların bile } \\
\text { doğrulukları sorgulanabilir }\end{array}$ & .463 \\
\hline & & Açıkladığı Varyans \% & 10.191 \\
\hline & & Açıklanan Toplam Varyans \% & 40.572 \\
\hline
\end{tabular}


Doğrulayıcı faktör analizi (DFA).AFA sonucunda elde edilen 27 madde ve üç faktörden oluşan yapının yeterli uyum indeksleri verip vermediğini belirlemek ve MOEİÖ’nün yapı geçerliğine ilişkin ek kanıt elde etmek için DFA uygulanmıştır. DFA'da sınanan modelin yeterliğini ortaya koymak üzere pek çok uyum indeksi kullanılmaktadır. Bu çalışmada DFA için Ki-Kare Uyum Testi (Chi-Square Goodness), karşılaştırmalı uyum indeksi (Comparative Fit Index, CFI), normlaştırılmamış uyum indeksi (Non-Normed Fit Index, NNFI), fazlalık uyum indeksi (Incremental Fit Index, IFI),tahmin hatalarının ortalamasının karekökü (Root Mean Square Error of Approximation, RMSEA) ve standartlaştırılmış hata kareleri ortalamasının karekökü (Standardized Root Mean Square Residual, SRMR) uyum indeksleri incelenmiştir. CFI, NNFI ve IFI indeksleri için .90 değeri kabul edilebilir uyuma ve .95 değeri mükemmel uyuma işaret etmektedir (Bentler, 1980; Bentler \& Bonett, 1980; Marsh, Hau, Artelt, Baumert,\& Peschar, 2006). RMSEA için .08değeri kabul edilebilir uyum ve .05 değeri mükemmel uyum ölçütü olarak alınmaktadır (Brown \& Cudeck, 1993; Byrne \& Campbell, 1999). SRMR için ise .05 değeri mükemmel uyumu ve .10 değeri kabul edilebilir uyumu ifade etmektedir (Hu \& Bentler, 1999; Kline, 2011). Yapilan DFA'da, elde edilen modelin uyum indeksleri incelenmiş ve minimum $\chi^{2}$ değerinin $\left(\chi^{2}=772.69\right.$, $N=315, p=.00)$ anlamlı olduğu görülmüştür.Uyum indeksi değerleri ise, CFI=.90, $\mathrm{NNFI}=.90$, IFI=.90, RMSEA=.066 ve $\mathrm{SRMR}=.089$ olarak bulunmuştur.Sinanan modelin yeterliğini ortaya koymak amacıyla incelenen uyum indekslerine ilişkin kabul edilebilir ve mükemmel uyum değerleri ile DFA'dan elde edilen uyum indeksi değerleri ve bu doğrultuda ortaya çıkan sonuçlar Tablo 3'te gösterilmiştir.

Tablo 3

Araştırmada İncelenen Uyum İndekslerine İlişkin Mükemmel ve Kabul edilebilir Uyum Değerleri ile DFA'dan Elde Edilen Uyum İndeksi Değerleri

\begin{tabular}{|c|c|c|c|c|}
\hline $\begin{array}{l}\text { Uyum } \\
\text { İndeksleri }\end{array}$ & $\begin{array}{l}\text { Mükemmel } \\
\text { Uyum Ölçütü }\end{array}$ & $\begin{array}{l}\text { Kabul Edilebilir } \\
\text { Uyum Ölçütü }\end{array}$ & $\begin{array}{c}\text { DFA } \\
\text { Sonuçları }\end{array}$ & Sonuç \\
\hline$X^{2} / \mathrm{sd}$ & $0 \leq X^{2} / \mathrm{sd} \leq 2$ & $2 \leq X^{2} / \mathrm{sd} \leq 3$ & 2.38 & Kabul edilebilir uyum \\
\hline CFI & $.95 \leq \mathrm{CFI} \leq 1.00$ & $.90 \leq \mathrm{CFI} \leq .95$ & .90 & Kabul edilebilir uyum \\
\hline NNFI & $.95 \leq \mathrm{NNFI} \leq 1.00$ & $.90 \leq \mathrm{NNFI} \leq .95$ & .90 & Kabul edilebilir uyum \\
\hline IFI & $.95 \leq \mathrm{IFI} \leq 1.00$ & $.90 \leq \mathrm{IFI} \leq .95$ & .90 & Kabul edilebilir uyum \\
\hline RMSEA & $.00 \leq \mathrm{RMSEA} \leq .05$ & $.05 \leq \mathrm{RMSEA} \leq .08$ & .066 & Kabul edilebilir uyum \\
\hline SRMR & $.00 \leq \mathrm{SRMR} \leq .05$ & $.05 \leq \mathrm{SRMR} \leq .10$ & .089 & Kabul edilebilir uyum \\
\hline
\end{tabular}

Tablo 4'deki uyum indekslerine ilişkin mükemmel ve kabul edilebilir uyum ölçütleri, DFA'dan elde edilen üç faktörlü modelin uyumlu olduğunu göstermektedir. Üç boyutlu modele ilişkin faktör yükleri Şekil 1'de görülmektedir.Şekil 1'de görülebileceği gibi, ÖÇBOİ alt boyutu için faktör yükleri .44 ile .72 arasında, ÖYBOİ alt boyutu için .29 ile .67 arasında ve TBDVOİ alt boyutu için faktör yükleri ise 26 ile .79 arasında değişmektedir. 
Şekil 1. MOEİÖ’ye İlişkin Path Diyagramı, Faktör Yükleri ve Hata Varyansları

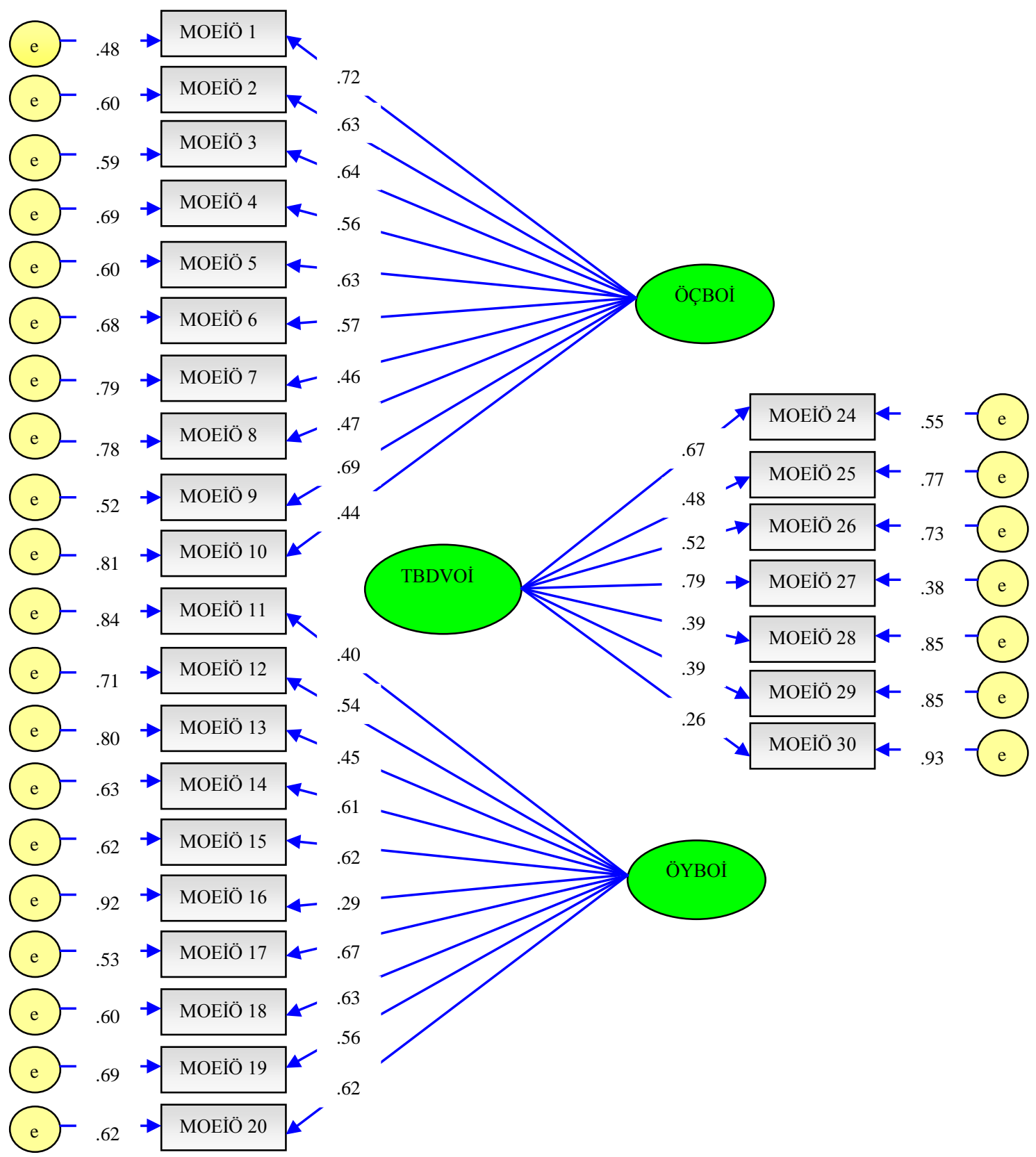

Uyum geçerliği.Epistemolojik inançlara ilişkin literatür incelendiğinde, matematiğe yönelik gelişmiş epistemolojik inançlara sahip olan öğrencilerin, gelişmemiş epistemolojik inançlara sahip olan öğrencilere göre, akademik başarılarının daha yüksek olduğu görülmektedir (Tang, 2010). Bu noktadan hareketle, MOEİÖ'nün uyum geçerliği kapsamında, öğrencilerin ölçeğin alt boyutlarından aldıkları puanlar ile matematik başarıları arasındaki korelasyon hesaplanmıştır. Öğrencilerin bir önceki yıla ait karnelerindeki matematik dersi notları, matematik başarı puanı olarak alınmıştır. ÖÇBOİ alt boyutundan alınan puanların gelişmiş epistemolojik inançlara işaret ettiği, ÖYBOİ ve TBDVOİ alt boyutlarındanalınan yüksek puanların ise gelişmemiş epistemolojik inançlara işaret ettiği göz önünde bulundurularak, ÖÇBOİ alt boyutu ile matematik başarısı arasında pozitif; ÖYBOİ ve TBDVOİ alt boyutları ile matematik 
başarısı arasında negatif bir ilişkinin bulunduğu hipotezi test edilmiştir. Korelasyon analizi sonucunda, ÖÇBOİ ile matematik başarısı arasında pozitif yönde [ $n=315, r=.48$, $p<.001$ ], ÖYBOİ ve TBDVOİ ile matematik başarısı arasında negatif yönde [ $n=315$ ve sırasıyla $r=-.25 p<.001, r=-.26, p<.001]$ anlamlı ilişkilerin bulunduğu saptanmıştır. $\mathrm{Bu}$ bulgular, MOEİÖ’nün uyum geçerliğinin sağlandığına dair bir kanıt olarak değerlendirilmiştir.

Güvenirlik.MOEİÖ’nün güvenirliği, iç tutarlık ve test-tekrar test güvenirlik yöntemleri ile hesaplanmıştır. İç tutarlık katsayıları, ÖÇBOİ alt ölçeği için .84, ÖYBOİ alt ölçeği için .81 ve TBDVOİ alt ölçeği için .71 olarak bulunmuştur. Ölçeğin test-tekrar test güvenirliğini belirlemek için 91 öğrenci üzerinde iki hafta ara ile iki uygulama yapılmıştır. Birinci ve ikinci uygulama arasındaki tutarlığı ortaya koymak amacıyla, iki uygulamadan elde edilen puanlar arasındaki korelasyonkatsayıları hesaplanmıştır. Testtekrar test güvenirlik katsayıları, ÖÇBOİ alt ölçeği için .96, ÖYBOİ alt ölçeği için .95 ve TBDVOİ alt ölçeği için .95 olarak hesaplanmıştır. Güvenirlik katsayıs1 .70 ve üzerinde olan ölçeklerin güvenilir kabul edildiği (Domino \& Domino, 2006; Fraenkel, Wallen,\& Hyun, 2012; Leech, Barlett,\& Morgan, 2005; Pallant, 2005; Tezbaşaran, 1997; Şeker \&Gençdoğan, 2006; Urbina, 2004) göz önüne alındığında, hesaplanan güvenirlik katsayılarının yeterli olduğu söylenebilir. Güvenirlik analizine yönelik sonuçlar Tablo 4’te sunulmuştur.

Tablo 4

MOEİÖ’nün İç Tutarlılık ve Test-Tekrar Test Yöntemleriyle Hesaplanan Güvenirlik Katsayılart

\begin{tabular}{lcc}
\hline Alt Ölçekler & İç Tutarlık (Cronbach Alpha) & Test-Tekrar Test \\
\hline ÖÇBOİ & .84 & .96 \\
ÖYBOİ & .81 & .95 \\
TBDVOİ & .71 & .95
\end{tabular}

Madde analizi.MOEİÖ'de yer alan maddelerin ayırt edicilik düzeylerini belirlemek ve toplam puanı yordama gücünü saptamak amacıyla düzeltilmiş madde toplam korelasyonu hesaplanmış ve \%27'lik alt-üst grup karşılaştırmalarına yer verilmiştir. Düzeltilmiş madde toplam korelasyonun hesaplanmasında Pearson Momentler Çarpımı Korelasyonu kullanılmıştır.\%27’likalt-üst grup karşılaştırmalarında ise ilişkisiz örneklemlert testinden yararlanılmıştır. Madde analizi sonucunda elde edilen bulgular Tablo 5’te sunulmuştur. 
Tablo 5

MOEİ̈ Madde Analizi Sonuçları

\begin{tabular}{|c|c|c|c|c|c|c|c|}
\hline \multirow[b]{2}{*}{ Alt Boyut } & \multicolumn{6}{|c|}{ Madde Çıkarıldığında } & \\
\hline & Madde No & $\begin{array}{c}\text { Ölçek } \\
\text { Ortalamas1 }\end{array}$ & $\begin{array}{c}\text { Ölçek } \\
\text { Varyans1 }\end{array}$ & $\begin{array}{l}\text { Ölçek } \\
\text { Alfas1 }\end{array}$ & $\begin{array}{c}\text { Madde Toplam } \\
\text { Korelasyonu }\end{array}$ & $t$ & \\
\hline \multirow{10}{*}{$\begin{array}{c}\text { ÖÇBOİ } \\
N=315 \\
\text { Cronbach } \\
\text { alpha }=.84\end{array}$} & MOEİÖ1 & 32.51 & 49.37 & .811 & .66 & $14.86^{*}$ & \multirow{10}{*}{$\begin{array}{l}s d=169 \\
*^{*} p<.001\end{array}$} \\
\hline & MOEİÖ2 & 32.53 & 50.56 & .819 & .58 & $13.16^{*}$ & \\
\hline & MOEİÖ3 & 33.47 & 49.47 & .820 & .57 & $15.15^{*}$ & \\
\hline & MOEİÖ4 & 32.86 & 51.90 & .825 & .52 & $11.99 *$ & \\
\hline & MOEİÖ5 & 32.72 & 49.99 & .821 & .56 & $14.22 *$ & \\
\hline & MOEİÖ6 & 33.18 & 51.38 & .826 & .51 & $11.06 *$ & \\
\hline & MOEİÖ7 & 32.01 & 55.33 & .833 & .43 & $8.42 *$ & \\
\hline & MOEİÖ8 & 32.71 & 52.41 & .833 & .44 & $9.34^{*}$ & \\
\hline & MOEİÖ9 & 33.14 & 48.03 & .814 & .63 & $20.36^{*}$ & \\
\hline & MOEIÖÖ10 & 32.27 & 54.91 & .834 & .41 & $8.32 *$ & \\
\hline \multirow{10}{*}{$\begin{array}{c}\text { ÖYBOİ } \\
N=315 \\
\text { Cronbach } \\
\text { alpha }=.81\end{array}$} & MOEİÖ11 & 22.69 & 54.31 & .80 & .37 & $9.67 *$ & \multirow{10}{*}{$\begin{array}{l}s d=172 \\
*^{*} p<.001\end{array}$} \\
\hline & MOEİÖ12 & 23.43 & 53.03 & .79 & .49 & $10.81^{*}$ & \\
\hline & MOEİÖ13 & 22.88 & 53.58 & .80 & .43 & $11.19 *$ & \\
\hline & MOEIÖÖ17 & 23.46 & 51.54 & .79 & .52 & $12.24 *$ & \\
\hline & MOEİÖ18 & 23.03 & 50.94 & .78 & .56 & $14.85 *$ & \\
\hline & MOEIÖ16 & 22.19 & 58.07 & .81 & .28 & $5.86^{*}$ & \\
\hline & MOEİÖ17 & 23.12 & 51.26 & .78 & .59 & $14.83 *$ & \\
\hline & MOEIÖ18 & 23.61 & 51.92 & .78 & .53 & $12.50 *$ & \\
\hline & MOEİÖ19 & 22.85 & 52.59 & .79 & .51 & $12.62 *$ & \\
\hline & MOEİÖ20 & 23.26 & 51.96 & .78 & .53 & $13.57 *$ & \\
\hline \multirow{7}{*}{$\begin{array}{c}\text { TBDVOİ } \\
N=315 \\
\text { Cronbach } \\
\text { alpha }=.71\end{array}$} & MOEİÖ24 & 17.11 & 21.44 & .64 & .54 & $14.39 *$ & \multirow{7}{*}{$\begin{array}{l}s d=208 \\
*_{p}<.001\end{array}$} \\
\hline & MOEIÖ25 & 16.84 & 22.62 & .68 & .38 & $10.38 *$ & \\
\hline & MOEİÖ26 & 16.95 & 22.36 & .67 & .42 & $11.67 *$ & \\
\hline & MOEİÖ27 & 16.75 & 20.26 & .61 & .62 & $16.95 *$ & \\
\hline & MOEİ̈28 & 17.22 & 23.69 & .69 & .34 & $8.64 *$ & \\
\hline & MOEİÖ29 & 16.62 & 24.23 & .69 & .33 & $8.43^{*}$ & \\
\hline & MOEİÖ30 & 17.29 & 25.16 & .71 & .27 & $6.46^{*}$ & \\
\hline
\end{tabular}

Tablo 5'teki bulgular incelendiğinde, \%27'lik alt ve üst grupların madde puanlarındaki farklara ilişkin $t$ değerlerlerinin ÖÇBOİ alt ölçeği için 8.32 ile 20.36 arasında ( $s d=169, p<.001)$, ÖYBOİ alt ölçeği için 5.86 ile 14.85 arasında $(s d=172$, $p<.001)$, TBDVOİ alt ölçeği için ise 6.46 ile $16.95(s d=208, p<.001)$ arasında değiştiği görülmektedir.Tablo 6'ya göre ayrıca, madde toplam korelasyonuna ilişkin sonuçlar, ÖÇBOİ alt ölçeği için .41 ile .66 arasında, ÖYBOİ alt ölçeği için .28 ile .59 arasında, TBDVOİ alt ölçeği için ise .27 ile .62 arasında sıralanmaktadır. Madde toplam korelasyonu yorumlanırken değeri .30 ve üzerinde olan maddeler,ölçülecek özelliği ayırt etme açısından yeterli kabul edilmektedir (Büyüköztürk, 2010; Erkuş, 2012; Field, 2009). ÖYBOİ alt ölçeğinde yer alan 16. madde ile TBDVOİ alt ölçeğinde yer alan 30. 
madde dışındaki maddelerin tamamı bu ölçütü sağlar niteliktedir. Bununla birlikte, \%27’lik alt-üst grup karşılaştırmaları sonucu elde edilen $t$ değerlerinin düzeltilmiş madde toplam korelasyonu .30'un altında olan 16 ve 30. maddeler için de anlamlı olduğu görülmektedir. Alt ve üst grup arasındaki farklara ilişkin $t$ değerlerinin anlamlı olması maddenin ayırt ediciliği için bir kanıt olarak değerlendirilmektedir (Erkuş, 2012). $\mathrm{Bu}$ bulgulardan hareketle, ölçekte yer alan maddelerin tamamının ayırt edici olduğu söylenebilir.

MOEİÖ’nün puanlarının değerlendirilmesi.MOEİÖ'de 27madde bulunmaktadır.Ölçekte“Kesinlikle Katıllyorum(5)”dan“Kesinlikle Katılmıyorum(1)”a değişen5’li Likert tipi bir derecelendirme kullanılmıştır. Ölçek, ÖÇBOİ, ÖYBOİ ve TBDVOİ olmak üzere üç boyutla bir yapıya sahiptir. ÖÇBOİ alt boyutunda, 10 madde bulunduğundan bu boyuttan alınabilecek en yüksek puan 50, en düşük puan ise 10'dur. $\mathrm{Bu}$ alt boyutta yer alan maddelerin tamamı olumlu olup tersten puanlanan madde bulunmamaktadır. Aynı şekilde, ÖYBOİ alt boyutunda 10 madde yer aldığından bu boyuttan alınabilecek en yüksek puan 50, en düşük puan ise 10'dur. Bu boyuttaki maddelerin tamamı öğrenmenin yeteneğe bağlı olduğunu destekleyen olumlu maddelerdir.Dolayısıyla ÖYBOİ boyutunda da tersten puanlanan madde bulunmamaktadır.TBDVOİ boyutunda ise yedimadde yer almaktadır. Bu boyuttan alınabilecek en yüksek puan 35, en düşük puan ise yedidir. Bu boyuttaki maddelerin beşi olumludur (tek bir doğrunun var olduğunu destekleyen). Kalan ikimadde ise olumsuz (tek bir doğrunun olduğunu desteklemeyen) olup tersten puanlanmıştır.MOEİÖ’nün alt boyutlarından alınan puanların yükselmesi, öğrencilerin ilgili boyuta ait inançlarının yüksek düzeyde olduğu anlamına gelmektedir. MOEİÖ’nün ÖÇBOİ alt ölçeğinden alınan yüksek puanlar matematik alanına yönelik gelişmiş/olgunlaşmış epistemolojik inançlara işaret ederken; ÖYBOİ ve TBDVOİ alt ölçeklerinden alınan yüksek puanlar matematik alanına yönelik gelişmemiş/olgunlaşmamış epistemolojik inançlara işaret etmektedir.

\section{Sonuç ve Tartışma}

$\mathrm{Bu}$ araştırmada, öğrencilerin matematik alanına yönelik epistemolojik inançlarını̈lçmeye olanak tanıyacak geçerli ve güvenilir bir ölçme aracının geliştirilmesi amaçlanmıştır. MOEİÖ geliştirilirken, Schommer (1990) tarafından geliştirip Deryakulu ve Büyüköztürk $(2002,2005)$ tarafından Türkçeye uyarlanan genel epistemolojik inanç ölçeğindeki ÖÇBOİ,ÖYBOİ ve TBDVOİ boyutları dikkate alınmıştır. ÖÇBOİ'yi yansıtan 10 madde, ÖYBOİ'yi yansıtan 11 madde ve TBDVOİ'yi yansitan 14 madde olmak üzere toplam 35 maddeden oluşan bir madde havuzu oluşturulmuştur. Ölçeğin kapsam ve görünüş geçerliğini sağlamak için uzman görüşü alınmıştır. Uzman görüşleri doğrultusunda, biriÖÇBOİ'yi, dördüTBDVOİ'yi yansıtan toplam beş madde ölçekten çıkarılmıştır. Bu işlemin ardından, ölçekte ÖÇBOİ boyutunu yansitan 10 madde, ÖYBOİ boyutunu yansitan 10 madde ve TBDVOİ boyutunu yansıtan 10 madde olmak üzere toplam 30 madde kalmıştır. 30 madde, “Kesinlikle 
Katılıyorum(5)"dan“Kesinlikle Katılmıyorum(1)"a değişen5’li Likert tipi bir derecelendirme ile araştırma grubundaki öğrencilere uygulanmıştır.

MOEİÖ’nün yapı geçerliği için AFA ve DFA uygulanmıştır. AFA sonucunda üç madde ölçekten çıkarılmış, kalan 27 maddenin toplam varyansın \%40.57'sini açıklayan üç faktörlü bir yapıya sahip olduğu belirlenmiştir.Faktörlerde toplanan maddelerin içerikleri ve kuramsal çerçevedikkate alınarak birinci faktör ÖÇBOİ, ikinci faktör ÖYBOİ ve üçüncü faktör TBDVOİ olarak adlandırılmıştır. AFA'dan elde edilen üç faktörlü yapının yeterli uyum indeksi verip vermediğini belirlemek ve MOEİÖ’nün yapı geçerliğine ilişkin ek kanıt elde etmek için DFA uygulanmıştır. DFA'dan elde edilen bulgular, MOEİÖ’ye ilişkin üç faktörlü yapıya ait uyum indekslerinin yeterli olduğunu göstermiştir. AFA'da açıklanan varyans oranı için \%30 ve üzerindeki değerlerin ölçüt olarak alındığı (Bayram, 2009; Büyüköztürk, 2010), ölçekte yer alan maddelere ait faktör yüklerinin .30 alt sınırının(Büyüköztürk, 2010; Costello \& Osborne, 2005; Foster, 2002; Pallant, 2005; Schriesheim \& Eisenbach, 1995)üzerinde olduğu ve DFA'dan elde edilen uyum indekslerinin kabul edilebilir sınırlar içerisinde yer aldığ 1 düşünüldüğünde MOEİÖ'nün yapı geçerliğinin sağlandığı söylenebilir.

MOEİO’nün uyum geçerliği için, öğrencilerin ölçeğin alt boyutlarından aldıkları puanlar ile matematik başarıları arasındaki korelasyon hesaplanmıştır. Öğrencilerin bir önceki yıla ait karnelerindeki matematik dersi notları, matematik başarı puanı olarak alınmıştır.Korelasyon analizinden elde edilen bulgular, öğrencilerin matematik alanına yönelikepistemolojik inançları ile matematik başarıları arasındaki ilişkinin epistemolojik inançlara ilişkin literatür ile uyumlu olduğunu göstermiştir.

MOEIÖ’nün güvenirliği, iç tutarlık ve test-tekrar test yöntemleriyle incelenmiştir. Hesaplanan iç tutarlık katsayıları ÖÇBOİ alt ölçeği için .84, ÖYBOİ alt ölçeği için .81 ve TBDVOİ alt ölçeği için .71 şeklindedir. Test-tekrar test güvenirlik katsayıları ise, ÖÇBOİ alt ölçeği için .96, ÖYBOİ alt ölçeği için .95 ve TBDVOİ alt ölçeği için .95 olarak bulunmuştur. Güvenirlik katsayıs1 .70 ve üzerinde olan ölçeklerin güvenilir kabul edildiği (Anastasi, 1982; Muijs, 2004; Nunnaly \& Bernstein, 1994; Sipahi, Yurtkoru,\& Çinko, 2010; Stangor, 2010) göz önüne alındığında, hesaplanan iç tutarlık ve test-tekrar test güvenirlik katsayıları ölçeğin güvenirliğine yönelik bir kanıt olarak değerlendirilebilir. İnançların uzun sürede şekillenen ve değişime direnç gösteren yapılar olması (Nespor, 1987), MOEİÖ'nün test-tekrar test güvenirliğine yönelik birinci ve ikinci uygulama arasındaki korelasyonun oldukça yüksek olmasının nedeni olabilir.

MOEİÖ’de yer alan maddelerin toplam puanı yordama gücünü belirlemek ve ayırt edicilik düzeylerini saptamak amacıyla madde analizi yapılmıştır. Madde analizi kapsamında, düzeltilmiş madde toplam korelasyonu incelenmiş ve \%27'lik alt-süt grup karşılaştırmalarına yer verilmiştir. Analiz sonucunda, düzeltilmiş madde toplam korelasyonlarının ÖÇBOİ alt ölçeği için .41 ile .66 arasında, ÖYBOİ alt ölçeği için .28 ile .59 arasında, TBDVOİ alt ölçeği için ise .27 ile .62 arasında sıralandığı ve \%27’lik alt ve üst grup arasındaki farklara ilişkin $t$ değerlerin ölçekte yer alan tüm maddeler için anlamlı olduğu belirlenmiştir. Bu bulgular, MOEİÖ'de yer alan maddelerin tamamının ayırt edici olduğuna işaret etmektedir. 
Araştırmada, MOEIÖ’nün psikometrik özelliklerini incelemek amacıyla gerçekleştirilen istatistiksel analizlerden elde edilen bulgular, ölçeğin öğrencilerin matematik alanına yönelik epistemolojik inançlarını belirlemede geçerli ve güvenilir bir araç olarak kullanılabileceğini ortaya koymaktadır. Sonuç olarak, Türk kültürüne, öğrencilerin matematik odaklı epistemolojik inançlarını ölçmek amacıyla kullanılabilecek bir ölçek kazandırmayı amaçlayan bu çalışma ile öğrencilerin matematiksel bilginin ve matematik öğrenmenin doğasına yönelik inançlarını ölçmede kullanılabilecek yeterli psikometrik özelliklere sahip bir ölçme aracına ulaşıldığ söylenebilir.

\section{Öneriler}

Alanyazın incelendiğinde, Türk kültüründe fizik, kimya, kamu yönetimi, iktisat, özel eğitim ve Türkçe eğitimi gibi farklı alanlara yönelik epistemolojik inanç ölçeklerinin bulunduğu görülmektedir. Ancak, ulusal literatürde öğrencilerin matematik odaklı epistemolojik inançlarını belirlemek amacıyla kullanılabilecek bir ölçeğe rastlanmamıştır. MOEİÖ'nün geliştirilmesinin amaçlandığı bu çalışmanın literatürdeki bu boşluğu dolduracağına inanılmakta ve dolayısıyla önemli olduğu düşünülmektedir. Bununla birlikte, bu ölçek geliştirme çalışmasının yalnızca ortaöğretim öğrencilerinden oluşan bir çalışma grubu üzerinde yürütülmüş olması, MOEİÖ’nün sadece ortaöğretim öğrencilerinde geçerliği kanıtlanmış bir ölçme aracı olduğu anlamına gelebilir. Bu bağlamda, ölçeğin geçerliği ve güvenirliği için farklı örneklemler üzerinde yapılacak çalışmalar önem arz etmektedir.

$\mathrm{Bu}$ araştırmada, MOEİ̈’nün uyum geçerliği kapsamında, öğrencilerin MOEİÖ'de yer alan alt ölçeklerden aldıkları puanlar ile matematik başarıları arasındaki ilişki incelenmiştir. Epistemolojik inançlara ilişkin alanyazın incelendiğinde, epistemolojik inançların; ders çalışma stratejileri (Deryakulu, 2004), öğrenme yaklaşımları (Cano, 2005; Hofer \& Pintrich, 1997; Rodríguez \& Cano, 2006; Schommer, Crouse, \& Rhodes, 1992), yansıtıcı düşünme (Phan, 2006), problem çözme becerisi (Aksan \&Sözer, 2007), yaşam boyu öğrenme eğilimi (Bath \& Simth, 2002) ve değer tercihleri (Başçiftçi, Güleç, Akdoğan, \&Koç, 2011) gibi çok sayıda değişken ile ilişkili olduğu görülmektedir. Bu noktadan hareketle, matematik odaklı epistemolojik inançların söz konusu değişkenler ile nasıl bir ilişki içerisinde olduğunu belirlemeye yönelik araştırmaların yürütülmesiönerilebilir. MOEİÖ’nün kullanılacağı araştırmaların yürütülmesi, ölçeğin ölçme gücüne katkı sağlayacak olması açısından oldukça önemlidir.

Literatür incelendiğinde, epistemolojik inançların genel mi, alan odaklı mı yoksa hem genel hem de alan odaklı mı olduğunu belirlemek amacıyla yapılan araştırmaların genellikle farklı kültürlerde gerçekleştirildiği, Türk kültüründe ise genel ve alan odaklı epistemolojik inançlar arasındaki ilişkiyi incelemeye yönelik sınırlı sayıda araştırma (Eren, 2006) olduğugörülmektedir.Epistemolojik inançların şekillenmesinde kültürelfaktörlerin etkili bir rol oynadığı (Buehl \& Alexander, 2006; Chan \& Elliot, 2004; Schommer, 2004) göz önüne alındığında, genel ve epistemolojik inançlar arasındaki ilişkinin de kültürel özelliklerden etkileneceği düşünülebilir. Dolayısıyla, 
Türk kültüründe genel ve alan odaklı epistemolojik inançlar arasındaki ilişkiyi belirlemeye yönelik araştırmalar, epistemolojik inançlara ilişkin genel - alan odaklı tartışmalarına 1şık tutabilir. Bu bağlamda, araştırma kapsamında geliştirilen MOEİÖ kullanılaraköğrencilerin genel ve matematik odaklı epistemolojik inançları arasındaki ilişkilerin inceleneceği araştırmalarla, genel ve alan odaklı epistemolojik inançlar ile ilgili literatüre katkı sağlanabilir.

\section{Kaynakça}

Abedalaziz, N.,\& Akmar, S.N. (2012). Epistemology beliefs about mathematical problem solving among Malaysian students.OIDA International Journal of Sustainable Development,5(1), 59-74.

Aksan, N.,\& Sözer, M.A. (2007). Üniversite öğrencilerinin epistemolojik inançları ile probleme çözme becerileri arasındaki ilişkiler. Ahi Evran Üniversitesi Ĕ̆itim Fakültesi Dergisi,8(1), 31-50.

Anastasi, A. (1982). Psychological testing.New York: MacMillan PublishingCo. Inc.

Aypay, A. (2011). Epistemolojik inançlar ölçeğinin Türkiye uyarlaması ve öğretmen adaylarının epistemolojik inançlarının incelenmesi.Eskişehir Osmangazi Üniversitesi Sosyal Bilimler Dergisi, 12(1), 1-15.

Başçiftçi, F., Güleç, N., Akdoğan, T.,\& Koç, Z. (2011, Nisan). Öğretmen adaylarının değer tercihleri ile epistemolojik inançlarının incelenmesi.2. Uluslararası Eğitimde Yeni Yönelimler ve Uygulamaları Sempozyumunda sunulmuş sözlü bildiri, Antalya, Türkiye.

Bath, D.M.,\& Smith, C.D. (2009).The relationship between epistemological beliefs and the propensity for lifelong learning.Studies in Continuing Education,31(2), 173189.

Baxter-Magolda, M. (1992) Knowing and reasoning in college: Gender-related patterns in students' intellectual development.San Francisco: Jossey-Bass.

Bayram, N. (2009). Sosyal bilimlerde SPSS ile veri analizi. Bursa: Ezgi Kitabevi.

Beers, S. E. (1988). Epistemological assumptions and college teaching: Interactions in the college classrooms. Journal of Research and Development,21(4), 87-94.

Belenky, M., Clinchy, B.M., Goldberger, N.R.,\& Tarule, J.M. (1986).Women's ways of knowing. New York: Basic Books.

Bendixen, L.D., \& Schraw, G. (2001). Why do epistemological beliefs affect ill-defined problem solving?Paper presented at the Annual Meeting of the American Educational Research Association, Seattle, WA.

Bentler, P.M. (1980). Multivariate analysis with latent variables: Causal modeling. Annual Review of Psychology, 31, 419-456.

Bentler, P.M.,\& Bonett, D.G. (1980).Significance tests and goodness of fit in the analysis of covariance structures.Psychological Bulletin,88, 588-606. 
Brown, M., \& Cudeck, R. (1993). Alternative ways of assessing model fit. InK. Bollen \& J. Long(Eds.), Testingstructural equation models(pp. 136-162). London: Sage Publications.

Buehl, M.M.,\& Alexander, P.A.(2006).Examining the dual nature of epistemological beliefs.International Journal of Educational Research, 45, 28-42.

Buehl, M.M., Alexander, P.A., \& Murphy, P.K.(2002). Beliefs about schooled knowledge: Domain specific or domain general? Contemporary Educational Psychology,27, 415-449.

Büyüköztürk, Ş. (2010). Sosyal bilimler için veri analizi el kitabı.Ankara: Pegem Akademi Yayınları.

Calderhead, J. (1996). Teachers: Beliefs and knowledge. In D. Berliner \& R. Calfee (Eds.), Handbook of educational psychology(pp. 709-725). New York: Macmillan Library Reference.

Can, B.,\& Arabacioğlu, S. (2009). The observation of the teacher candidates' epistemological beliefs according to some variables.Procedia Social and Behavioral Sciences, 1(1), 2799-2803.

Cano, F. (2005). Epistemological beliefs and approaches to learning: Their change through secondary school and their influence on academic performance. British Journal of Educational Psychology,75, 203-221.

Cattell, R.B. (1978). The scientific use of factor analysis in behavioral and life sciences. New York: Plenum.

Chan, K.,\& Elliot, R.G. (2004). Epistemological beliefs across cultures: Critique and analysis of beliefs structure studies. Educational Psychology,24(2), 123-142.

Colby, G.T. (2007). Students' epistemological beliefs of mathematics when taught using traditional versus reform curricula in rural Maine high schools (Unpublished master's thesis). University of Maine, Maine.

Costello, A.B.,\& Osborne, J.W. (2005). Best practices in exploratory factor analysis: Four recommendations for getting the most from your analysis. Practical Assessment Research \& Evaluation, 10(7), 1-9.

Cramer, D. (2003).Advanced quantitative data analysis. Philadelphia, PA: McGrawHill.

Çokluk, Ö., Şekercioğlu, G.,\& Büyüköztürk, Ş. (2012). Sosyal bilimler için çok değişkenli istatistik: SPSS ve LISREL uygulamalart. Ankara: Pegem Akademi Yayıncilık.

Croceker, L.,\& Algina, J. (1986).Introduction to classical and modern test theory. Fort Worth, TX: Holt, Rinehart and Winston Inc.

Cronbach, L.J. (1984). Essentials of psychological testing. New York: Harper Row.

Demirli, C., Türel, Y.K., \& Özmen, B. (2010, Nisan). Bilişim teknolojileri öğretmen adaylarının epistemolojik inançlarının incelenmesi.Uluslararası Eğitim 
Teknolojileri Sempozyumunda sunulmuş sözlü bildiri, Boğaziçi Üniversitesi, İstanbul, Türkiye.

Deryakulu, D. (2004). Üniversite öğrencilerinin öğrenme ve ders çalışma stratejileri ile epistemolojik inançları arasındaki ilişki. Kuram ve Uygulamada Eğitim Yönetimi,38, 230-249.

Deryakulu, D. (2006). Epistemolojik inançlar. Y. Kuzgun \&D. Deryakulu(Ed.) içinde, Eğitimde bireysel farklılıklar(ss. 261-289). Ankara: Nobel Yayın Dağıtım.

Deryakulu, D.,\& Büyüköztürk, Ş. (2002). Epistemolojik inanç ölçeğinin geçerlik ve güvenirlik çalışması. Eğitim Araştırmaları Dergisi,2(8), 111-125.

Deryakulu, D.,\& Büyüköztürk, Ş. (2005). Epistemolojik inanç ölçeğinin faktör yapısının yeniden incelenmesi: Cinsiyet ve öğrenim görülen program türüne göre epistemolojik inançların karşılaştırılması. Ĕ̈itim Araştırmaları Dergisi, 18, 57-70.

DeVellis, R. F. (2003). Scale development: Theory and applications. Newbury Park: Sage Publications.

Domino, G.,\& Domino, M.L. (2006).Psychological testing: An introduction. Cambridge: Cambridge University Press.

Dweck, C.,\& Leggett, E. (1988).A social-cognitive approach to motivation and personality.Psychological Review,95, 256-273.

Enman, M.,\& Lupart, J. (2000). Talented female students' resistance to science: an exploratory study of post-secondary achievement motivation, persistence, and epistemological characteristics. High Ability Studies,11(2), 161-178.

Eren, A. (2006). Üniversite ögrencilerinin genel ve alan-odaklı epistemolojik inançlarının incelenmesi (Yayımlanmamış doktora tezi). Abant İzzet Baysal Üniversitesi, Bolu.

Erkuş, A. (2012). Psikolojide ölçme ve ölçek geliştirme. Ankara: Pegem Akademi Yayınları.

Ertekin, E., Dilmaç, B., Delice A., \& Aydın, E. (2009). Teachertrainees' epistemologicalbeliefs: Effects of gender, institution, anddiscipline (mathematics / socialsciences). New Educational Review,18(2), 184-196.

Ertekin, E., Dilmaç, B., Yazıcı, E.,\& Peker, M. (2010). The relationship between epistemological beliefs and teaching anxiety in mathematics.Educational Research and Review, 5(10), 631-636.

Eynde, P.O., De Corte, E.,\& Verschaffel, L. (2006). Epistemic dimensions of students' mathematics-related belief systems. International Journal of Educational Research,45, 57-70.

Ferguson, E.,\& Cox, T. (1993). Exploratory factor analysis: A users' guide. International Journal of Selection and Assessment, 1(2), 84-94.

Foster, J. (2002). Data analysis using SPSS for Windows (v8-10). London: Sage Publications. 
Fraenkel, J.R., Wallen, N.E.,\& Hyun, H.H. (2012).How to design and evaluate research in education. New York: McGraw Hill.

Field, A. (2009). Discovering statistics using SPSS. London: SAGE Publications Ltd.

Fishbein, M.,\& Ajzen, I. (1975). Belief, attitude, intention and behavior: An introduction to theory and research. Reading, MA: Addison-Wesley Publishing.

Gill, M.G., Ashton, P.T.,\& Algina, J. (2004).Changing preservice teachers' epistemological beliefs about teaching and learning in mathematics: An intervention study.Contemporary Educational Psychology, 29, 164-185.

Gorsuch, R.L. (1983). Factor analysis. Hillsdale, NJ: Lawrence Erlbaum.

Hacıömeroğlu, G. (2011). Sınıf öğretmeni adaylarının matematiksel problem çözmeye ilişkin inançlarını yordamada epistemolojik inançlarının incelenmesi. Buca Eğitim Fakültesi Dergisi,30, 206-220.

Hair, J.F., Anderson, R.E., Tatham, R.L.,\& Grablowsky, B.J. (1979). Multivariate data analysis. Tulsa, OK: Pipe Books.

Hammer, D. (1994). Epistemological beliefs in introductory physics.Cognition and Instruction,12(2), 151-183.

Hofer, B. (2000) Dimensionality and differences in personal epistemology.Contemporary Educational Psychology,25, 378-405.

Hofer, B.,\& Pintrich, P.R. (1997).The development of epistemological theories: Beliefs about knowledge and knowing and their relation to learning. Review of Educational Research,67(1), 88-144.

Hu, L.T., \& Bentler, P.M. (1999). Cutoff criteria for fit indexes in covariance structural analysis: Conventional criteria versus new alternatives. Structural Equation Modeling,6, 1-55.

Hutcheson, G.,\& Sofroniou, N. (1999).The multivariate social scientist. London: Sage.

Hazır-Bıkmaz, F. (2002). Fen Öğretiminde öz yeterlilik inancı. Eğitim Bilimleri ve Uygulama, 1(2), 197-2010.

Jehng, J.C.J., Johnson, S.D., \& Anderson, R.C. (1993). Schooling and students' epistemological beliefs about learning.Contemporary Educational Psychology,18(1), 25-35.

Kline, R.B. (1994). An easy guide to factor analysis.New York: Routledge.

Kline, R.B. (2011). Principles and practice of structural equation modeling. New York: The Guilford Press.

Koballa, T.R., \& Crowley, F.E. (1985).The influence of attitude on science teaching and learning.School Science and Mathematics,85(3), 222-232.

Krows, A.J.(1999). Preservice teachers' belief systems and attitudes toward mathematics in the context of a progressive elementary teacher preparation 
program (Unpublished doctoral dissertation).The University of Oklohama, Oklohoma.

Kurt, F. (2009). Cinsiyetin, sinıf seviyesinin ve ĕgitim gördükleri alanların, öğrencilerin epistemolojik inançları üzerindeki etkisi (Yayımlanmamış yüksek lisans tezi). Ortadoğu Teknik Üniversitesi, Ankara, Türkiye.

Leech, N.L.,Barlett, K.C.,\& Morgan, G.A. (2005). SPSS for intermediate statistics: Use and interpretation. Mahwah, NJ: Lawrence Erlbaum Associates.

Limon, M. (2006).The domain generality-specificity of epistemological beliefs: A theoretical problem, a methodological problem or both? International Journal of Educational Research, 45, 7-27.

Mansour, N. (2009). Science teachers' beliefs and practices: Issues, implications and research agenda. International Journal of Environmental \& Science Education,4(1), 25-48.

Marsh, H.W., Hau, K.T., Artelt, C., Baumert, J.,\& Peschar, J.L.(2006). OECD’s brief self-report measure of educational psychology's most useful affective constructs: Cross-cultural, psychometric comparisons across 25 countries. International Journal of Testing,6(4), 311-360.

Martin, C.R. \& Newell, R.J. (2004).Factor structure of the hospital anxiety and depression scale in individuals with facial disfigurement.Psychology Health and Medicine,9(3), 327-336.

Mori, Y. (1997, August) Epistemological beliefs and language learning: What do language learners believe about their learning?Paper presented at the Annual Meeting of the American Educational Research Association,Chicago, IL.

Mori, Y. (1999). Epistemological beliefs and language learning beliefs: What do language learners believe about their learning? Language Learning,49(3), 377-415.

Muijs, D. (2004). Doing quantitative research in education with SPSS. London: SAGE Publications.

Muis, K.R., Bendixen, L.R.,\& Haerle, F.C. (2006). Domain-generality and domainspecificity in personal epistemology research: Philosophical and empirical reflections in the development of a theoretical framework. Educational Psychology Review,18(1), 3-54.

Nespor, J. (1987). The role of beliefs in the practice of teaching.Journal of Curriculum Studies,19, 317-328.

Nunnaly, J.,\& Bernstein, I. (1994).Psychometric theory. New York: McGraw-Hill.

Olson, J.M., Roese, N.J.,\& Zanna, M.P. (1996).Expectancies. In E.T.Higgins \& A. W.Kruglanski (Eds.), Social psychology: Handbook of basic principles (pp. 211238). New York: Guilford Press.

Özşeker, M., Canpolat, M.,\& Yıldız, L. (2011). Beden eğitimi öğretmen adaylarının epistemolojik inançları ve benlik saygıları arasındaki ilişki. Niğde Üniversitesi Beden Eğitimi ve Spor Bilimleri Dergisi, 5(2), 155-164. 
Pajares, F. (1992). Teachers' beliefs and educational research: Cleaning up a messy construct. Review of Educational Research, 62(3), 307-332.

Pallant, J. (2005). SPSS survival manual: A step by step guide to data analysis using SPSS for Windows. Australia: Australian Copyright.

Paulsen, M. B., \& Feldman, K. A. (1999).Epistemological beliefs and self-regulated learning.Journal of Staff, Program, and Organizational Development,16, 83-91.

Paulsen, M.B., \& Wells, C.T.(1998).Domain differences in the epistemological beliefs of college students.Research in Higher Education,39(4), 365-384.

Phan, H.P.(2006). Examination of student learning approaches, reflective thinking and epistemological beliefs: A latent variables approach. Electronic Journal of Research Educational Psychology, 4(3), 577-610.

Phan, H.P. (2008). Predicting change in epistemological beliefs, reflective thinking and learning styles: A longitudinal study. British Journal of Educational Psychology, 78, 75-93.

Pintrich, P.R.,\& Schunk, D.H.(2002).Motivation in education: Theory, research and applications. Upper Saddle River, NJ: Merrill Prentice Hall.

Richardson, V. (2003).Pre-Service teachers' beliefs. In J. Raths \& A. C. McAninch (Eds.),Teacher beliefs and classroom performance: The impact of teacher education (pp. 1-22). Greenwich, CT: Information Age Publishing.

Rodríguez, L.,\& Cano, F. (2006): The epistemological beliefs, learning approaches and study orchestrations of university students. Studies in Higher Education,31(5), 617636.

Roth, W.M., \& Roychoudhury, A. (1994).Physics students' epistemologies and views about knowing and learning.Journal of Research in Science Teaching,31(1), 5-30.

Ruddick, S. (1996) Reason's feminity: A case for connected knowing.In N. Goldberger, J. Tarule, B. Clinchy,\&M. Belenky(Eds.), Knowledge, difference and power (pp. 248-273).New York: Basic Books.

Rukavina, I., \& Daneman, M. (1996).Integration and its effects in acquiring knowledge about competing scientific theories from text.Journal of Educational Psychology,88, 272-287.

Ryan, M.P.(1984). Monitoring text comprehension: Individual differences in epistemological standards.Journal of Educational Psychology,76, 248-258.

Schoenfeld, A.H. (1989). Exploration of students' mathematical beliefs and behavior.Journal for Research in Mathematics Education,20, 338-355.

Schommer, M. (1990).Effects of beliefs about the nature of knowledge on comprehension.Journal of Educational Psychology,82(3), 498-504.

Schommer, M.A.(1998). The influence of age and education on epistemological beliefs.British Journal of Educational Psychology,68(4), 551-562. 
Schommer, M. (2004).Explaining the epistemological belief system: Introducing the embedded systemic model and coordinated research approach.Educational Psychologist,39(1), 19-29.

Schommer, M., Crouse, A., \& Rhodes, N. (1992). Epistemological beliefs and mathematical text comprehension: Believing it is simple does not make it so. Journal of Educational Psychology,84, 435-443.

Schommer, M.A., Duell, O. K.,\& Barker, S. (2003). Epistemological beliefs across domains using Biglan's classification of academic disciplines.Research in Higher Education,44(3), 347-366.

Schommer, M.A., \& Walker, K. (1995).Are epistemological beliefs similar across domains? Journal of Educational Psychology, 87(3), 424-432.

Schraw, G., Bendixen, L.D., \& Dunkle, M.E.(2002). Development and validation of the epistemic belief inventory (EBI). In B.K. Hofer \& P.R. Pintrich (Eds.), Personal epistemology: The psychology of beliefs about knowledge and knowing (pp. 261275). Mahwah, NJ: Lawrence Erlbaum.

Schriesheim, C.A., \& Eisenbach, R.J.(1995). An exploratory and confirmatory factor analytic investigation of item wording effects on obtained factor structures of survey questionnaire measures. Journal of Management,21(6), 1177-1193.

Steiner,L.A.(2007).The effect of personal and epistemological beliefs on performance in a college developmental mathematics class (Unpublished doctoral dissertation).Kansas State University, Kansas.

Sipahi, B., Yurtkoru, S., \& Çinko, M. (2010). Sosyal bilimlerde SPSS’le veri analizi. İstanbul: Beta Basım Yayım Dağıtım.

Stangor, C. (2010). Research methods for the behavioral sciences. Wadsworth.

Stockton, J.C. (2010). A study of the relationships between epistemological beliefs and self-regulated learning among advanced placement calculus students in the context of mathematical problem solving (Unpublished doctoral dissertation).Kennesaw State University, Kennesaw, GA.

Strobel, J., Cernusca, D.,\& Jonassen, D.H.(2011).Differentmajors - different epistemological beliefs?Academic Exchange Quarterly,12, 208-211.

Şeker, H.,\& Gençdoğan, B. (2006). Psikolojide ve eğitimde ölçme aracı geliştirme. Ankara: Nobel Yayın Dağıtım.

Tang, J. (2007). Exploratory and confirmatory factor analysis of epistemic beliefs questionnaire about mathematics for Chinese junior middle school students.Journal of Mathematics Education,3(2), 89-105.

Tavşancıl, E. (2009). Tutumların ölçülmesi ve SPSS ile veri analizi. Ankara: Nobel Yayın Dağıtım.

Tezbaşaran, A. (1997). Likert tipi ölçek hazırlama kılavuzu. Ankara: Türk Psikologlar Derneği. 
Tsai, C.C.(2000). The effects of STS-oriented instruction on female tenth graders' cognitive structure outcomes and the role of student scientific epistemological beliefs. International Journal of Science Education,22(10), 1099-1115.

Urbina, S. (2004).Essentials of psychological testing. NJ: John Wiley \& Sons. Inc.

Walker-Wheeler, D.L.(2007).The development and construct validation of the epistemological beliefs survey for mathematics (Unpublished doctoral dissertation). Oklahoma State University, Oklahoma.

Wood, P.K., \& Kardash, C.A.(2002).Critical elements in the design and analysis of studies of epistemology. In B.K. Hofer \& Paul R. Pintrich (Eds.), Personal epistemology: The psychology of beliefs about knowledge and knowing (pp. 231260). Mahwah, NJ: Erlbaum.

Y1lmaz, Ö. (2007). Öğrencilerin epistemolojik ve matematik problemi çözümlerine yönelik inançlarının problem çözme sürecine etkisinin araştırılması (Yayımlanmamış yüksek lisans tezi). Marmara Üniversitesi, İstanbul. 